\title{
Taphonomies of landscape: investigating the immediate environs of Çatalhöyük from prehistory to the present
}

\author{
Mark P.C. Jackson and Sophie V. Moore \\ Newcastle University, UK, and Brown University, USA \\ m.p.c.jackson@newcastle.ac.uk
}

\begin{abstract}
The landscape immediately surrounding the site of Çatalhöyük preserves topographic and ceramic evidence dating from prehistoric times to the present day. This article presents the results of a programme of investigation of the landscape conducted through analysis of remote-sensing, map and field-survey data, with particular emphasis on the first and second millennia AD. The concept of taphonomy, usually defined in archaeology as the process of change after deposition, is applied to the transformation of the settled landscape from its Neolithic origins to its present status as a UNESCO World Heritage Site. Taphonomy serves as a linking concept as we explore how past landscapes are mobilised and translated into the ever-changing present.
\end{abstract}

Özet

Çatalhöyük yerleşiminin hemen çevresindeki alan, tarih öncesi zamanlardan günümüze kadar topografik ve seramik kanıtları sunmaktadır. Bu makalede, uzaktan algılama metodu, harita ve yüzey araştırması verilerinin analizi yoluyla ve özellikle M.S. birinci ve ikinci bin yıllara yoğunlaşarak yapılan bir araştırma programının sonuçları sunulmaktadır. Arkeolojide, genellikle birikim sonrası değişim süreci olarak tanımlanan tafonomi kavramı, bu çalışmada yerleşilmiş arazinin Neolitik kökenlerinden günümüzde UNESCO Dünya Miras Alanı statüsüne dönüşmesine uygulanmaktadır. Tafonomi, geçmişte arazilerin nasıl değiştiğini ve günümüzde sürekli değişen bu hale nasıl geldiğini gösteren bir geçiş kavramı olarak hizmet etmektedir.

$\mathrm{F}$ irst identified as a site by archaeologist James Mellaart in the late 1950s, Çatalhöyük, which consists of two topographical features - the East Mound and the West Mound - is renowned for its occupation between $7100 \mathrm{BC}$ and $5600 \mathrm{BC}$ (for the recent revisions to the chronology of the site, see Bayliss et al. 2015; Orton et al. in preparation); the later history of the site and its environs is, however, less well-known. Excavations under Mellaart were conducted over four seasons between 1961 and 1965, and focused on the Neolithic (Mellaart 1962; 1963; 1964; $1966 ; 1967)$, but no further work took place on site until a major 25-year programme of excavations began under the direction of Ian Hodder in 1993 (Hodder 1996); this phase ended in 2017. Meanwhile, an extensive survey has also been conducted on the wider Konya plain, together with a programme of environmental sampling around the site which have helped to set Çatalhöyük within a broader

context (Baird 1996; 2004). As soon as survey and excavation began in 1993, it became clear that there was evidence of later activity on the mounds dating from the Hellenistic period onwards (Matthews 1996: 88-99), but, while carefully excavated, the record from these later periods has been published only sporadically by individual teams working on particular areas of the site (Kwiatkowska 2009; Cottica et al. 2012). A programme of research on post-Chalcolithic material across both mounds and the surrounding area began in 2011, including structures, the immediate landscape context and mortuary evidence (Moore, Jackson 2014; Yeomans 2014; Hordecki 2015). Nevertheless, there is a noticeable gap between the very detailed evidence and narrative for Neolithic Çatalhöyük and that for the period between the end of prehistoric settlement on the West Mound and the present day (for the occupation of the West Mound, see Biehl et al. in 
preparation). While this 'gap' is in part due to the disparity between the exceptional Neolithic evidence and the relative paucity of evidence from later archaeological levels, it is also a result of taphonomy, scholarly process, research questions and funding criteria. As the recent period of 25 years of research comes to an end, this article, and forthcoming work by the team of post-Chalcolithic specialists, aims to address the less well-known story of Çatalhöyük in the first and second millennia AD (Marciniak, Moore in preparation). This article primarily addresses the immediate landscape context of Çatalhöyük. It is suggested that taking a holistic view of the more recent material on the site will help to refine our understanding of the nature of activity at Çatalhöyük.

The purpose of this paper is to consider patterns of use and continuity in the immediate environs of Çatalhöyük. We consider how various processes contributed to the transformation of archaeological evidence between formation and analysis; these are transformations which we describe as a form of taphonomy. The best-preserved evidence for the wider landscape dates from the 20th century, but significant evidence remains from earlier periods, especially the first and second millennia AD. We will present the results of analysis of 20th-century maps and satellite imagery, as well as a programme of field-walking and landscape survey which took place in July 2013. Our central aim is to contribute to our understanding of the landscape of Çatalhöyük throughout time, by asking how the landscape immediately around Çatalhöyük has transformed up to the present day. Here we wish to consider the rate of change over the long term, and the taphonomy of the landscape. Secondly, we aim to address whether survey projects limited to specific 'sites' by official definitions and laws are able to contribute to the more holistic goals associated with assemblage theories as set out, for example, in the European Landscape Convention (ELC; Council of Europe 2000) or by current large-scale eastern Mediterranean survey projects.

At the heart of landscape archaeology is the central semantic problem of defining what a 'landscape' actually is. Definitions have moved from a common-sense understanding of landscape as 'where we are', through various permutations of place (Bloch 1995), perceived vista (Porteous 1990: 4) and chorography (Shanks, Witmore 2010). More recently, landscape has come to be seen as something that humans do (Given 2013: 8). Within the potential variety of ways of conceptualising archaeological landscapes, this article suggests that the two most fruitful lines of enquiry are those which engage most closely with past human engagement with the world: the landscape as perceived (Council of Europe 2000: 9) and the landscape as enacted (Ingold 1993: 153-54). We consider landscape to be a combination of a thing which is perceived, a physical thing and a collection of human actions.
Landscape studies exist at different scales. The Turkish government permit requirements of 2013, which prohibited ceramic collection on surveys, meant that our survey was unusual that year; it was allowed only because we were limited to the area within the third-degree border of the excavation permit for Çatalhöyük. This legal structure resulted in a considerably different kind of dataset to those of the large-scale surveys conducted in other areas of Turkey during the 1990s and 2000s, during which artefacts were collected across large areas as part of interdisciplinary analyses (for example Matthews, Glatz 2009). While having this holistic goal, we sought to make the most of the delimited third-degree area around the 'site'. Studies like ours, which use field-walking, ceramic analysis and retrogressive map analysis, complemented by the decades of interdisciplinary research at Çatalhöyük, work towards producing a type of holistic landscape analysis in line with the current theoretical preoccupations of the discipline of landscape archaeology. The growing body of assemblage theory within this particular field has had much the same effect as elsewhere in the wider sphere of archaeology: changing the questions asked of the data in order to consider the interaction between 'site' and 'landscape', and blurring the distinctions between our pre-supposed categories.

As long ago as the year 2000 the ELC asked us to consider

the territory as a whole, without distinguishing between the urban, peri-urban, rural and natural parts, or between parts that may be regarded as outstanding, every-day or degraded; it is not limited to cultural, artificial and natural elements; the landscape forms a whole whose constituent parts are considered simultaneously in their interrelations (Council of Europe 2000: 30).

In explicitly setting out a perspective which has a considerable affinity with current archaeological theory from relational and symmetrical schools, particularly the concept of a 'flat' or non-anthropocentric ontological position, the ELC challenges scholars to think beyond sitespecific archaeology and to consider the landscape as something which has been experienced by humans and animals throughout time (for experienced landscape, see Hamilakis 2013; for symmetrical archaeology and flat ontologies, see Witmore 2007).

Recent work in landscape theory promotes an attitude towards the archaeological study of landscape which seeks to move beyond the cataloguing and preservation of specific sites to engagement with all aspects of the built and natural environments (Council of Europe 2000: 30). This holistic approach to landscape incorporates the essentials of postmodern landscape theory built up by archaeologists, alongside geographers, landscape architects and social 
scientists over the last 20 years, and is predicated on the idea that landscapes are socially constituted and reflexively constitute aspects of society (for example Howard et al. 2013). In contrast to site-specific archaeology, the collective project of this style of landscape archaeology, employed in recent survey projects in the eastern Mediterranean, has advocated wider definitions of what makes a site (for example Bevan, Connolly 2004). This marks a fundamental shift towards an approach to the past which engages with assemblage theories popular in recent theoretical literature in order to create analyses which do not presuppose the importance of any single aspect of a network prior to analysis (for example Olsen et al. 2012). These theories have been effectively employed by Michael Given in his work on Cyprus to create an assessment of landscape which employs varied scales and types of analysis with the aim of addressing the landscape as a mutually constituted meshwork, produced through movement (Given 2013). A holistic approach to landscape therefore works at different scales to produce a more complete understanding of the experience of landscape by using all data sources available - both archaeological and non-archaeological; the traditional archaeological approach to landscape as the distribution area of sites is, by contrast, very different.

'Historic landscape characterisation' projects in Turkey have made novel use of the time-depth preserved in the morphology of the contemporary field systems (Crow, Turner 2009; Turner, Crow 2010; Green 2013). In a heavily agriculturally worked landscape, such as the Konya plain where our survey was located, characterising the historic nature of the space in any meaningful way becomes challenging because the contemporary field system has obliterated much of what existed before. In close proximity to Çatalhöyük, however, the taphonomy of landscape is radically different, with elements of the early modern landscape surviving in the morphology of contemporary fields. These fields provide a clue to the time-depth of the field systems around the site preserved into the current landscape and visible in satellite imagery. Retrogressive map analysis within the pre-defined boundaries of the site can grant us insight into the dramatic transformation of the broader landscape during the 20th century while also providing an indication of the much earlier field morphology preserved within the pre-modern field system.

For archaeologists, taphonomy was originally a borrowed concept, part of the bricolage of technical language and methodologies that shape the current discipline. Taphonomy is based on the Greek word $\tau$ ápos (taphos), which can be translated as a grave, tomb or funeral rites (Liddell, Scott 1968: 1761). Within geology, from where the technical term originates, taphonomy describes the radical change affecting organic materials as they fossilise (Holz, Simões 2005: 249-50). More generally within archaeology, the term is taken to mean change after deposition, a mobilisation of the concept developed from Michael Schiffer's formation theory (Schiffer 1972). It is a useful concept for us to employ here as we consider taphonomy beyond excavation contexts, in examining how the landscape has transformed over time. A taphonomy of landscape asks us to consider the processes through which landscapes change and how the features which survive have been kept static, preserved, fossilised, transformed and amplified.

The various bodies of archaeological evidence at Çatalhöyük (landscape, pottery, human remains, Neolithic architecture, etc.) have widely different taphonomies, and because of this they provide information at different scales of analysis. The evidence we have for rates of change in the landscape close to Çatalhöyük slides into and out of focus over the duration of settlement and landscape creation at the site. For the present day, the aerial imagery and retrogressive analysis of map data provide a reasonably precise and accurate chronology for the appearance of certain recent features around the mounds; the data are in focus and the resolution is good. For excavated prehistoric contexts, our understanding of taphonomic processes on site, including the mode of deposition, combined with radiocarbon dating and the recent programme of Bayesian statistics (which use contextual knowledge to model radiocarbon dates better), provides a remarkably refined chronology for the excavated levels of the East Mound (Bayliss et al. 2015); again, the data are in focus.

Precision and accuracy refer to different aspects of analysis: precision refers to the resolution of measurement while statements of accuracy indicate how closely results seem to correspond to reality. We might, for example, be able to assign a broad date range of 1,000 years to a coarseware sherd. While the assigned date could be accurate, the chronological range is so imprecise as to not be particularly useful in discussions of the occupied landscape. Our view of the past is analogous to looking through a telescope across space and time. At Çatalhöyük we have precise and accurate chronological data available for the Neolithic past which is where the archaeological lens has been focused. If we wish to keep a reasonable certainty of the accuracy of our data, our understanding becomes less precise as we move further away from the site and further away from the Neolithic, before sliding once again into focus in the present. This telescoping is an artefact of the taphonomy of landscape as much as it is a product of the focus of archaeology, in that our knowledge of the past is contingent on the level of preservation and the development of analytical tools relevant to the period. The precision of chronology inferred from coarse-ware sherds is currently low, but with collective publication of coarseware assemblages we can work towards better resolution. 
Our discussion examines some of the taphonomic factors which have affected the scale at which we are able to analyse the landscape beyond the mounds.

\section{Field survey}

Field survey was focused on the immediate environs of Çatalhöyük (fig. 1) and remained within the site-specific area defined by the third-degree permit boundary shown on figure 2 . The official perception of the site necessitated that we remained within this boundary and this allowed us to collect a sample of ceramic material (a collection strategy which would not have been legally possible in 2013 beyond the third-degree permit boundary). Our aspiration was for our research design to align with the common goal of modern landscape archaeology: to seek a holistic understanding of places in the past. We set out, therefore, to attempt to contribute to the understanding of the wider landscape by asking new questions of site-specific data within our defined area. One of our two central research questions thus asks whether small-scale surveys are 'worthwhile' in an age of intensive survey and big data.

Excavation at Çatalhöyük has revealed an extensive cemetery dating from the first and second millennia AD which covered all excavated areas of both the East Mound and the West Mound (fig. 1). The details of several sub-sets of the excavated graves have been published in a number of places and a synthetic publication is in preparation which will draw together the contextual and osteological data for the portion of the cemetery which remains unpublished (Cottica et al. 2012; Kwiatkowska 2009; Moore, Jackson 2014; Marciniak, Moore in preparation). Preliminary results of the Çatalhöyük historic cemeteries project are available within the Çatalhöyük archive reports and Heritage Turkey (Moore 2012; 2014a; 2014b; Jackson et al. 2013; Moore, Jackson 2014; Moore, Gamble 2015; 2016).

Our programme of survey, field-walking and ceramic collection was proposed with the intention of investigating the landscape context of the tell sites at Çatalhöyük in the first and second millennia $\mathrm{AD}$, contemporary with the Roman, Seljuk and Ottoman cemeteries. Earlier work by geomorphologists on the KOPAL team working at Çatalhöyük in the immediate vicinity of the mounds had demonstrated that the deposition of alluvium on the Konya plain (which has varied significantly throughout the Holocene) was likely to have preserved a ceramic signal from recent centuries relatively close to the surface, while sealing the prehistoric material under a layer of alluvium up to $3 \mathrm{~m}$ thick (Roberts et al. 2007: 533).

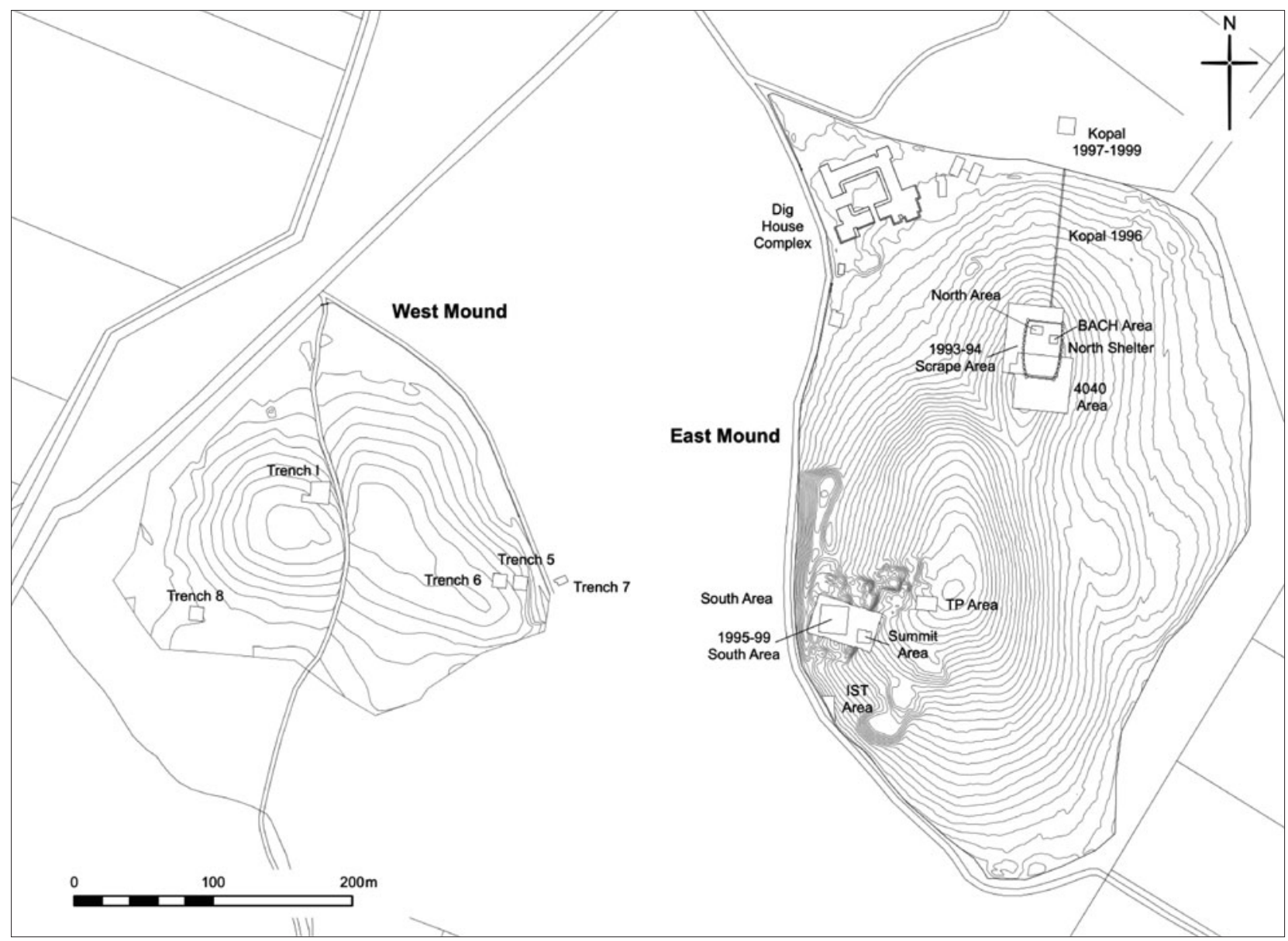

Fig. 1. Plan of Çatalhöyük, showing the mounds and excavation areas (C. Mazzucato). 


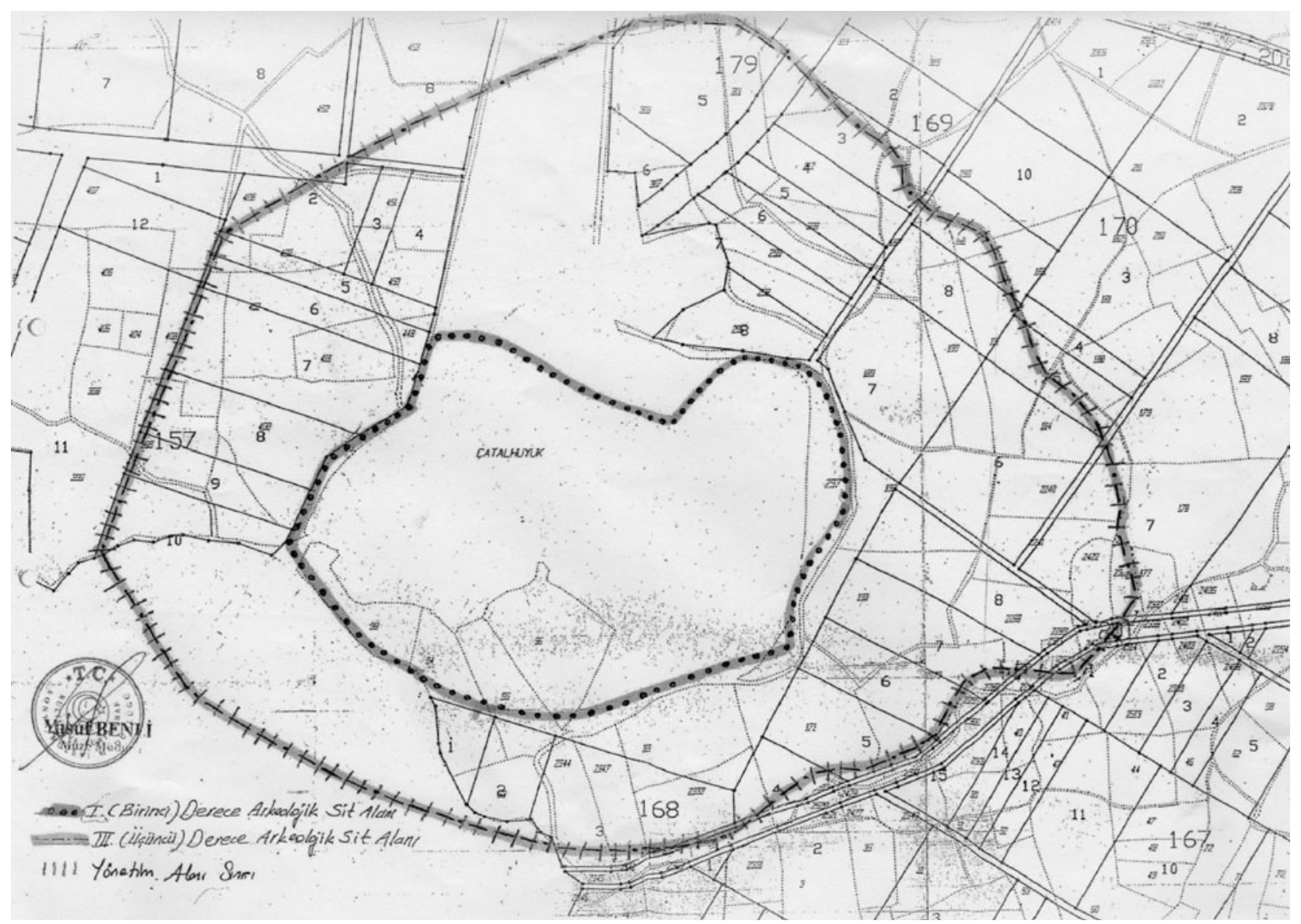

Fig. 2. The Çatalhöyük permit map, showing historical field data. The inner (dotted) line marks the first-degree permit area of Çatalhöyük; the outer (crossed) line marks the third-degree permit area. The modern rectilinear field system (with numbered fields) is recorded in dark lines; note how it respects the first-degree boundary. The pre-modern system of irregular fields (also numbered) is recorded in dotted lines; note how it intrudes between the mounds (Çatalhöyük Research Project).

Douglas Baird has reviewed taphonomic implications of the alluvial plain of the Çarşamba river for the survey of late antique settlements on the Konya plain (Baird 2004: 221-24, fig. 2), concluding that:

in the northern and eastern two thirds of the Çarşamba fan, the Roman - Early Byzantine land surface is preserved as it is in all areas off the fans ... [while] in southern and central areas of the Çarşamba fan the Roman - Early Byzantine levels are buried by 0.3 $0.5 \mathrm{~m}$ of alluvium (Baird 2004: 224).

The location of Çatalhöyük in the central area of the Çarşamba fan therefore suggests there might be reasonable preservation of material from the first and second millennia $\mathrm{AD}$ on the land surface. Good visibility of late antique sites was particularly likely as there is a preponderance of late antique and Byzantine sites located on slight rises across the Konya plain (Baird 2004: 224). Even if covered by a thin layer of alluvium, the landscape in the immediate environs of Çatalhöyük is extensively agricul- turally worked, making it likely that sherds near the surface would be upturned by the action of the plough. The combination of these factors meant we could expect a surface survey to be of particular potential value for addressing the issue of activity in the landscape in the period since antiquity.

\section{Satellite imagery and map analysis}

In exploring what the immediate environs of Çatalhöyük could tell us about past use of the landscape, continuity and demography, our starting points were the official permit map for the project (fig. 2), the topographic survey of Çatalhöyük conducted in 1993-1995 (Pollard et al. 1996), the site plan prepared by Peter Winchester in 1961 (Mellaart 1962: facing 44) and the satellite imagery available for the site (fig. 3). The permit map is from around 1993 at the latest, the beginning of the current phase of excavations, but it is not stamped with a date. Careful analysis of this official permit map for the project reveals the surveyed record of a complex network of fields surrounding Çatalhöyük. Comparison with Winchester's 


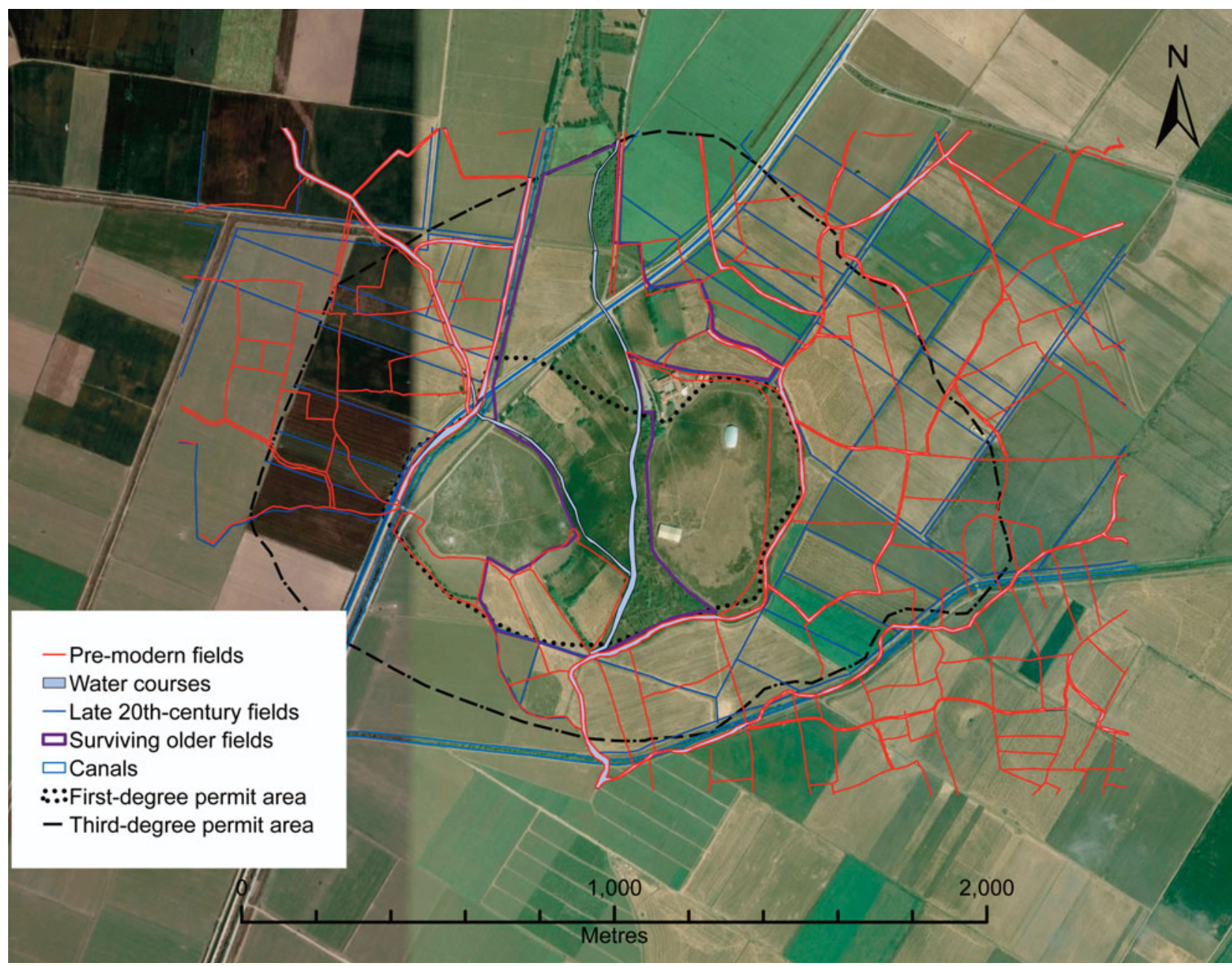

Fig. 3. Çatalhöyük satellite image, showing: the surviving older fields preserved in the third-degree area between the West and East Mounds; the pre-modern field boundaries (in red) and late 20th-century rectilinear field boundaries (in blue), both taken from the permit map (fig. 2); canals, identified via Google Earth; and water courses, taken from the map by Winchester (Mellaart 1962: facing 44) and the permit map. These data have been superimposed over a 2011 satellite image of the Çatalhöyük area (Google Earth Imagery; date 06/09/2011, accessed 17/12/2014; 37³9'59N, 32॰49’32 E; composite image compiled by M. Jackson).

plan enables us to make out ditches and water courses where two parallel lines are represented on the permit map, some of which represent the boundaries of fields. Significantly, the permit map shows two phases of surveyed field systems - a pattern of modern rectilinear fields and a complex pattern of older pre-modern field morphologies - both recorded as land-parcels of different periods on the permit map. These older fields are visible on figure 2 delineated by dotted, grey lines, behind the modern rectilinear fields shown in solid black lines. Each land-parcel - both old and new - is numbered on the map; they have a variety of shapes and orientations and their morphology reflects ways in which their boundaries often respect topographical and other features, including waterways, pathways and, as we will suggest, Çatalhöyük itself. Such records of fields, known as cadastral maps, are available for much of Turkey and reveal important contextual information for sites, informing us about the historic character of landscapes. While the modern system has been laid out largely without reference to the pre-existing pattern of land use, the complexity of the morphology of the earlier field boundaries reflects elements of landscape change probably over many centuries.

The modern field system immediately surrounding Çatalhöyük consists principally of large rectilinear fields arranged in strips running far across the landscape. Satellite imagery freely available via Google Earth shows that this surveyed system covers about $6 \mathrm{~km}$ north to south and about $2 \mathrm{~km}$ east to west; but it represents part of a much bigger series of similar modern rectilinear field systems in the region and found over much of the Konya plain. Such modern field systems with large rectilinear fields were imposed in the 20th century over this relatively flat landscape, removing much of the earlier system. These 
surveyed strips tend to be between about $290 \mathrm{~m}$ and $340 \mathrm{~m}$ wide and are subdivided into rectilinear fields measuring variously from ca $50 \mathrm{~m}$ to ca $300 \mathrm{~m}$ across.

Analysis of the 2011 satellite image of the Çatalhöyük area (fig. 3) shows very clearly the rectilinear field system of the contemporary landscape surrounding the site. Figure 3 also combines the two field systems recorded on the permit map with the 2011 satellite image. The modern field boundaries of the permit map (in blue) correspond closely to those shown in the 2011 satellite image. They do, however, differ slightly, showing that there has been some change in the intervening decades. The pattern of premodern fields (in red) reveals the complex landscape built up over a significant period of time. Comparison of the two systems reveals the dramatic extent of the change when the new field system was laid out.

The permit map seems to indicate that, while the modern field system impacts on the area inside the thirddegree permit area (dash-dot-dash on figure 3), it stops short of the first-degree area of the site. Although we do not have a specific date for this reorganisation, we can use this evidence to suggest that the laying out of this part of the modern field system appears to post-date the designation of the first-degree part of the site and probably the erection of the fence which was put up following Mellaart's work in the 1960s (Pollard et al. 1996: 61). These map data therefore suggest that the reorganisation took place in the latter half of the 20th century. It appears that, at the same time as the new field morphology was imposed, the water courses were also dramatically changed and are now quite different from those recorded by Winchester (Mellaart 1962: facing 44).

The local topography, including roads, canals and the scheduled area of the ancient site, has observably influenced the modern field morphology, which breaks down in the area around the mounds. This situation has helped to preserve some of the older field system at Çatalhöyük. Here we gain a glimpse of the early modern character of fields which continue to belong to the contemporary landscape.

Figures 2 and 3 together reveal that prior to the remodelling of the field systems on the Konya plain there was a complex pattern of field boundaries in this area. The satellite image shows traditional fields not recorded on the permit map but surviving in the area along the old course of the Çarşamba river between the northeast of the West Mound and the northwest of the East Mound. This network of older fields continues north towards the modern village at Küçükköy, following the line of the old Çarşamba river bed. We should note that the status of the first-degree archaeological perimeter of Çatalhöyük preserves this ancient field pattern, protecting it from a radical shift to the modern field layout.
Between the mounds, the small-scale contemporary farming practice has a significantly different taphonomy to that of the surrounding agricultural landscape. The relationship between the small farmhouse between the two mounds and the topography of the site has created a continued iteration of farming practices which were in place prior to the reorganisation of the landscape. This irregular field system and the associated current farming practices are uniquely valuable as part of the continued story of the site.

The comparison of the pre-modern field system with that of the modern, as preserved on the permit map, reveals the impact of large-scale landscape reorganisation. The rectilinear fields of the modern field system are suitable for intensive ploughing and the mechanised agriculture practised today, and reflect a complete transformation in the way the landscape is managed and owned. Their creation has also helped to bring about the removal of many potential social associations with former landscape features. While the new system of very large rectilinear fields visible today represents the majority of contemporary farming practice in the area, the preservation of the field boundaries of the earlier system between the mounds and to the north of Çatalhöyük reflects continuity in farming methods and land management, where the surviving fields are associated with mudbrick housing. The continuity of these practices seems to be facilitated here in part by the location of these fields between the two designated mounds.

If we now examine more closely the older field system shown in red on figure 3, we can see that the complicated morphology of the pre-modern field system reveals that it has been subject to change over a long period. Close examination of the pre-modern field system around Çatalhöyük reveals long linear features that radiate out from the West and East Mounds; these features include pathways as well as field boundaries (fig. 4). Retrogressive map analysis of the inherent relationships in these field boundaries reveals that these long linear features are usually respected by other features, such as fields with different morphologies. This may be taken as evidence for the relative age of the long radiating features, which must be older than the boundaries/features that respect them. Several of the longer linear features reflect waterways running near the site or which lie beside roads and paths which run around or up to one of the mounds themselves (fig. 4).

These long boundaries/features are complemented by shorter boundaries which are also visible radiating out from the mounds, and most likely represent the partial remains of other less well-preserved radiating features. In addition, it is possible to make out a series of boundaries running in a concentric pattern around the mounds. The outlines of these fields encircling the mound, represented in grey on figure 4, apparently respect the longer radial features. 


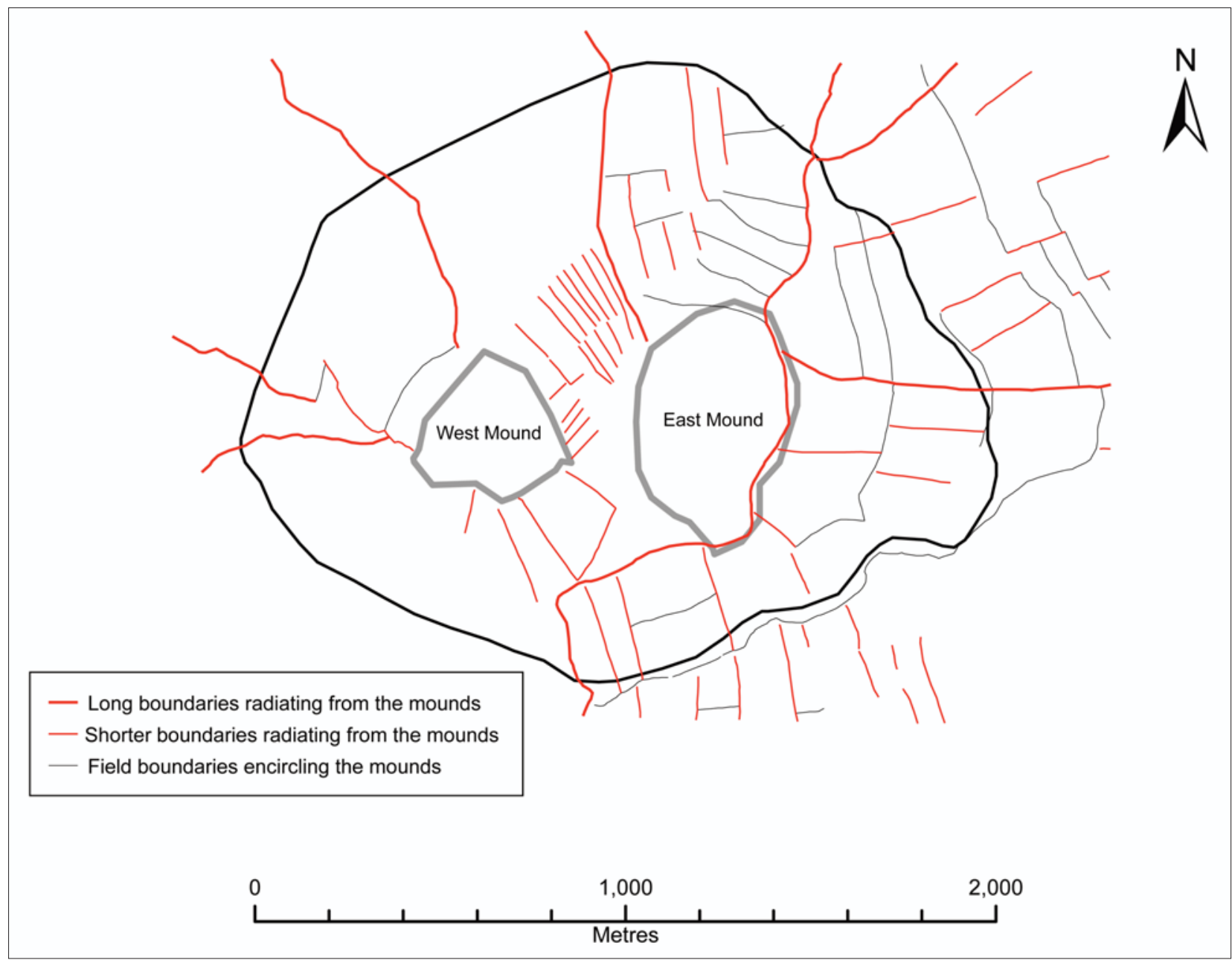

Fig. 4. Interpretation of features visible within the pre-modern field system (recorded on the permit map, fig. 2), showing: long boundaries radiating out from the mounds (highlighted as thick red lines); shorter field boundaries (shown as thin red lines) in a similar radiating pattern; and a series of boundaries (illustrated in grey) running in a concentric pattern around the mounds, which usually seem to respect the longer radial features (M. Jackson).

As a whole, therefore, the early modern field system, visible (in red) on figure 3 , records a complex landscape built up over time into the 20th century. Perhaps most intriguing for those interested in the role of Çatalhöyük in its landscape context are the vestiges of a comparatively old radiating field system preserved within this earlier 20th-century system; importantly, the two mounds at Çatalhöyük are the focal point of these radiating fields. Furthermore, while many of these fields were destroyed by the laying out of a new field system in the late 20th century, in the area between the mounds at Çatalhöyük today we have surviving evidence for the continued use of some of the oldest (radiating) landscape features in the area. Importantly, therefore, recent farming practice between the mounds at Çatalhöyük has helped to preserve elements of the landscape's ancient field morphology into the present.

The pattern of radiating field systems visible at Çatalhöyük is one that is typically associated with settlement mounds across the Middle East and which reflects the significant role of these focal places within landscapes especially their impact on the organisation of agricultural resources and communication routes (Casana 2013). Radiating field systems and concentric boundaries have also been linked at sites in both the Middle East and Europe to hydrology and land-irrigation practices, particularly in the period from the Bronze Age onwards (Wilkinson 2003; Mele et al. 2013). Broad, shallow 'swales' (30-60m wide but only $0.5-1 \mathrm{~m}$ deep) and deeper hollow ways that radiate from settlement mounds of multiple periods in southeastern Turkey, Syria, Iraq and Iran have long been identified (Poidebard 1934; van Liere, Lauffray 1954-1955; Wilkinson 1993; Ur 2003; Casana 2013). These features have been linked to the repeated movement of people, sheep and goats along trackways to their fields and grazing as well as between sites; they may have also had a role in channelling run-off (van Liere, Lauffray 1954-1955; Wilkinson 1993: 551-57; Ur 2003). 
The mean length of these hollows has been used as a proxy to establish the extent of cultivated land around settlements, linked to manuring and scatters of sherds (Wilkinson 1993: 560-61). Radial boundaries reveal the structuring role of the mounds within the surrounding landscape field system. Broad hollow ways of the third millennium $\mathrm{BC}$, for example, have been contrasted with narrow, later Byzantine- to Islamic-period features in the area of the Tell Hamoukar Survey (Ur 2003: 108).

Although the extant pattern of radial features around Çatalhöyük may not display the same morphology as the wide swales and deeper hollow ways identified elsewhere, previous discussions about such features do, nevertheless, help us to consider the use and origins of the radial boundaries at Çatalhöyük, such as, for example, the role of pathways in the structuring of land use and the enduring potential role of water. The differences may be due to the chronology and function of the radial fields around Çatalhöyük differing from those of these other sites or because the features are less visible on the Çatalhöyük permit map than in other landscapes where they survive on satellite imagery. Jesse Casana has noted the variable visibility of hollow ways on satellite imagery 'according to season, ground cover, soil moisture and other variables' (2013: 271) and the potential of LiDAR, multispectral images and radar data to provide more detailed data in the future.

At those sites where the movement of animals to and from settlements was necessary over a long period of time, a stable system of field boundaries was necessary in order to create a radial pattern of hollow ways between fields. Thus the complex land tenure (of the Bronze Age Near Eastern communities considered by Casana) may have constrained settlement sprawl and prevented land from being transferred from agricultural to residential use (Casana 2013: 268). Accordingly, these radial communication routes, providing necessary access to and from settlement mounds, may be considered to have had a structuring role.

With regards to the early farming communities of Europe and western Asia, there are strong social arguments for the employment of radial field systems. These are based on the equitable distribution of the most productive land which lies closest to the settlement and is therefore most intensively cultivated (Bogaard et al. 2011: 405). For the early farming communities of 'mega-sites', including Çatalhöyük, the practice of agriculture was arguably a compromise between proximity to cultivated land (increasing productivity and the ability to farm intensively) and the level of aggregation of the settlement (reducing vulnerability) (Bogaard, Isaakidou 2010: 195). A radial arrangement of fields would therefore form the most equitable division of the landscape, should the landscape be divided at all, and has previously been suggested as the model for a possible division of the landscape surrounding
Çatalhöyük (Charles et al. 2014: 89). Radial settlement systems have also been suggested for the arrangement of housing at Çatalhöyük, since separate groups of excavated houses can be divided by lines that radiate outwards (Hodder 2006: 95-101; 2014: 152-53).

The alluviation of the area around Çatalhöyük, especially from 7600-7100 cal. BC to $5100 \mathrm{cal}$. BC and ca. 3700 BC, means that much of the ancient landscape surface is concealed deep below the contemporary fields (Roberts et al. 1996; 1999; Hodder 2013: 13). We have seen that a plan view of the older field systems around Çatalhöyük reveals a complex horizontal stratigraphy but field boundaries in highly alluviated landscapes may also reflect complex vertical stratigraphy. Where land is often flooded people must maintain boundaries as the surrounding ground level rises. So when we observe a relatively old field boundary on the surface in an alluviated landscape, what we may be observing is the final form of a feature which has been continually added to over a very long period - rather than simply an old feature. Thus, in addition to considering the morphology of the field systems in plan as an indication of age, we must acknowledge that it is likely that the older field systems around Çatalhöyük may have a considerable depth of stratigraphy connected to buried ancient landscapes. For example, evidence from Italy has been used to show that although visible field boundaries may be relatively recent and wellmaintained, in an alluvial environment where maintenance is essential, such field boundaries may continue the lines of much older land parcels derived from much older field systems buried by many metres of alluvium as part of a dynamic system perpetuated over long periods through land use and organisation (Chouquer 2015: especially 126). It would be interesting to sample the boundaries of the field systems in the alluvial environment around Çatalhöyük in order to investigate their depth and chronology, and to consider questions raised by their morphology. What we are witnessing on the surface may be the later phases of field boundaries which belong to landscapes that have been buried for centuries; if this is the case, then plans of these boundaries provide proxy evidence for their buried predecessors.

Around Çatalhöyük, the field system provides a record of human activity in the landscape to complement the picture from the excavation of the site itself. Excavation on the mounds has indicated that the surrounding plain was used in the Neolithic period for grazing sheep and that a variety of resources was exploited from the local environment (Hodder 2014: 151). With the exception of the mounds themselves, the radial field system provides evidence for some of the earliest preserved elements of the landscape. Thus the structures of these field boundaries reveal ways that the people moved between the mounds 
and their surrounding environment. While we cannot yet provide a date for the origin of the radial pattern of fields, or link them to the radial patterns identified in relation to the buildings, we can suggest that the communication patterns which had Çatalhöyük as their local point of focus provided structure for the land tenure around the site and the movement of people in the past; whilst much of that system has broken down over time, elements of it were perpetuated into the 20th century and survive into the $21 \mathrm{st}$ century along the old line of the Çarşamba river between the mounds and running north to Küçükköy.

Whilst it is not possible, on the basis of the currently available data, to establish the origin of the radial field system, it is interesting to note that the radial architecture of Çatalhöyük dates primarily to the Neolithic period. Following the Early Chalcolithic occupation of the West Mound, there was a period of abandonment before the establishment of a short-lived Hellenistic settlement which was succeeded by use of the mounds as a place of burial from the Roman to Seljuk and Ottoman periods. Accordingly, the options for the establishment of the system are relatively limited.

While archaeologists have used evidence from the excavation to explore ways in which the alluvial landscape around Çatalhöyük offered considerable potential for exploitation and procurement, and geoarchaeologists have considered the impact of alluviation on the ancient land surface over time (Fairbairn 2005; Hodder 2013: 13-21), we might also consider how people may have influenced the hydrology of the area over the millennia. The older land parcels around Çatalhöyük visible on the permit map suggest an intensely exploited landscape. Since the Konya plain, now irrigated through modern engineering, was typically a well-watered and heavily alluviated area, one might question, in the light of the morphology of the fields around Çatalhöyük, whether it is possible to ascertain how irrigation was practised in the earlier land use. While we know that the plain was deliberately irrigated by engineers from the early 20th century onwards (Hoeffelman 1913; and see 'Discussion' below), we might question how the field systems were affected by flooding and whether in former times the people living on the Konya plain actively managed flooding in order to influence the inevitable formation of the alluvial environment, as an example of the landscape as a collection of human actions. The land parcels preserved in the contemporary landscape and in maps, such as the Çatalhöyük permit map, reflect the ways in which the land was organised for agriculture; it may be useful to consider such field systems alongside geoarchaeological investigations in order to explore whether they include evidence of the management of water resources for irrigation and/or alluviation for the enhancement of agricultural potential. Such practices have prece- dents, for example, in the Bronze Age and the postClassical period of the Po valley in Italy, where they are identifiable within the surviving field systems, and have been suggested for landscapes in the Middle East at various periods (Wilkinson 2003; Chouquer 2015: 136).

The differences between the two phases of field systems demonstrate that the process of laying out the modern field system marked a significant change in the appearance of the landscape. This change is presumably indicative of commensurate changes in social structure and landscape management in the area; this would have been, in part, made possible due to the industrial irrigation of the Konya plain in the early 20th century. The modern pattern of fields created a visual break from the past and contrasts with the preservation of not only the ancient site but also the preserved landscape and field system in the protected area around Çatalhöyük. Importantly, the new field morphology also represents changes in the practices carried out by people in the landscape. Thus the change reveals the different ways in which the landscape has been enacted and formed part of the lived experiences of local people. Survey in the early 1990s recorded that the West Mound had 'been used for many years for the storage of straw for fodder and mud-brick manufacture' (Pollard et al. 1996: 63). Such activities appear to represent the continuation here of older practices not facilitated by the rectilinear field system which is associated with mechanised farming. These activities were perhaps practised on the site because, in the late 20th century, this was the only part of the landscape where it was still possible. In the 1990s, the social anthropologist David Shankland noted that there is little detailed, systematic information published on the daily life of Anatolian villages (1996: 351). Against the background of major landscape change, our survey has contributed some surviving evidence for some of these practices.

Since the modern field system respects the outer limit of the first-degree archaeological research permit boundary, the area between the mounds, where the early field system survives, seems to have been preserved by the delimitation of the archaeological site of Çatalhöyük; the designation of the 'site' itself before the most recent phase of landscape development is therefore itself part of the taphonomy of the landscape.

\section{Field walking and ceramic survey}

The full methodology of the programme of field-walking conducted in 2013 is published in the Çatalhöyük Archive Report for that year (Jackson et al. 2013). In short, we used the existing fields as units within which we systematically collected pottery in order to locate distribution patterns. It should be noted that our permit was limited to the collection of ceramic material and did not allow for the recording 
or collection of other material such as lithics, which were nonetheless present in some of the area surveyed. The initial imagery used in the field in 2013 was from 2009; it was sufficient to observe field boundaries and create a polygonised field system within the permit limit described above. Between 2009 and 2013 a small number of boundaries had been altered, mostly by the subdivision of large fields into small strips to hold separate crops. Subsequently we used more recent satellite imagery from 2011 Google Earth. The small number of field-boundary changes suggests a relatively slow rate of change in the layout of the agricultural fields in this part of the Konya plain over the last 25 years.

Our ceramic collection methodology was informed by a long tradition of similar surveys in the Mediterranean (for example Francovich, Patterson 2000). Recent Mediterranean surveys, such as those conducted by Andrew Bevan and James Conolly (2004) and Michael Given and colleagues (2013), are intensive, wide ranging and intended to address the historic character of the landscape at a variety of scales; they assess the modern agricultural landscapes, the impact of visibility on archaeological recovery, site definition and characterisation, and the decisionmaking process behind ancient site formation (Bevan, Conolly 2004: 123; Crow et al. 2011). These goals are in line with the aims of the ELC in that they approach landscape from a non site-specific perspective and highlight the diachronic nature of change. Our ceramic collection was at a much smaller scale, conducted within the immediate environs of the mounds within the permitted area. All visible sherds within a metre either side of each transect were counted and a sample of the ceramics was collected and located to within $20 \mathrm{~m}$ of their origin. Our sampling strategy for collection included all bases, rim sherds, handles and decorated body sherds. One of our research aims was to establish whether a project focusing on a small area such as this could appreciably contribute to the broader understanding of landscape as advocated by the current application of assemblage theory to archaeological practice, set out in Given 2013, which axiomatically includes an understanding of specific sites, but advocates for a much more holistic research strategy. The limitations of both our collection strategy and survey area are a clear compromise between the conditions constraining the research and the desire to produce useful analysis.

Limitations on recording and collection strategies can be considered taphonomic in that the sample strategy adopted transforms our knowledge of landscape through recording, collection and study. Part of this taphonomy of collection is sample bias; those wares that are more visible (such as those with handles or glazed surface treatment) and/or durable (because of their manufacture) tend to be better represented in the collected sample than less conspicuous and durable material, or forms which are less identifiable. Less than a $100 \%$ collection sample strategy will tend to overemphasise material from particular periods; at the most basic level, this strategy emphasises periods when ceramics were common over those when they were not. This can result in the overrepresentation of particular periods due to the presence of highly visible wares such as Roman-period sigillata or later glazed pottery (Rutter 1983: 137-42; Sanders 2000: 173). Used in conjunction with other techniques, such as map analyses, ceramics have proven to be an essential tool in landscape survey for many decades, but it must be acknowledged that ceramics from some periods are less well-known and that they will not represent consistent proxy evidence for occupation or economic activity through time (Greene 2005: 43).

The total number of sherds counted in the field was 3,435 , providing a record of relative density of ceramic on the ground (fig. 5). The difference in the ground cover was recorded as a ranking of 'visibility' from 0 to 5 in each $20 \mathrm{~m}^{2}$. In presenting our results, however, we have chosen not to 'correct' mathematically the ceramic counts for poor visibility as the relationship between ceramic count and ground cover is not direct, and will not be consistent across the site. For example, the definite line dividing field 13 from 16 is likely to be a product of the lower visibility in field 16, rather than an accurate representation of the ceramics on the ground.

For the visualisation of the ceramic scatters, natural breaks were implemented (using the Jenks method: Jenks 1967) which put breaks at the largest jumps in the data, classifying the groups present on the ground into ten groups. Natural breaks were used rather than fixed intervals in order to simplify the visualisation and highlight the high-scoring ceramic clusters, while also showing areas where just one or two sherds were recovered. A zero value was used to highlight areas where no pottery or other metadata was present.

During analysis we identified five concentrations of pottery (shown in fig. 6). Areas of high ceramic density were identified north of the East Mound (field 1, cluster A), east of the East Mound (fields 13, 15, 16, 17, cluster B), south of both mounds (field 20, cluster C), south of the West Mound (fields 22, 23, 26, 27, 28, cluster D) and between the two mounds (fields 32 and 34, cluster E).

By quantifying surface material on a $20 \mathrm{~m}$ grid we are able to represent the data in figures 5 and 6 against the pattern of the pre-modern field system as well as within the contemporary fields. It is of note that cluster B, east of the East Mound, has a concentration that seems to be focused between the East Mound and the water course to the southeast of the site. Cluster A, north of the East Mound, cluster D, south of the West Mound, and cluster 


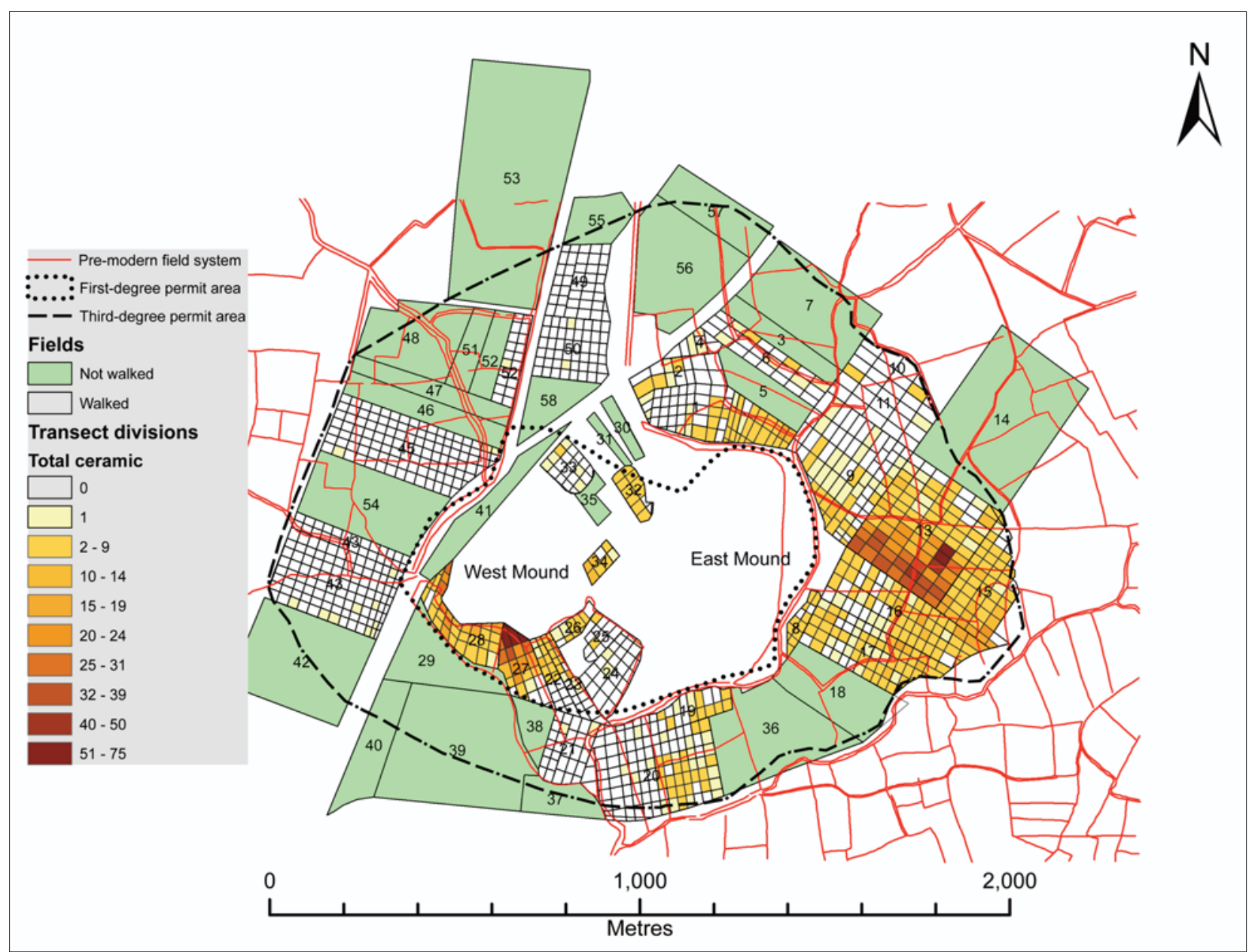

Fig. 5. The distribution of sherds counted on the surface in the transects walked within fields in 2013, presented together with the pattern of the pre-modern field system recorded on the permit map (M. Jackson, T. Sutcliffe, A. Turner).

$\mathrm{E}$, between the two mounds, are best understood in relation to the pre-modern system as shown on figure 5. The visibility of the surface material, however, relates to the contemporary agricultural use within the modern field system and the timing of collection within the crop cycle. The grid collection and comparison to earlier fields does at least enable us to see how the material fits within an earlier landscape context, but that impression is impaired by the reorganisation and later use of the fields.

The ceramic-fabric profiles of three of the identified clusters $-\mathrm{A}, \mathrm{B}$ and $\mathrm{C}-$ are similar, and so the ceramic data from these three clusters are presented together. The visibility in the fields surrounding cluster A is poor enough in places that it is possible that the scatter exists at similar concentration in fields 11 and 9 , between $\mathrm{A}$ and $\mathrm{B}$, and again in the unsurveyed fields 18 and 36 , between $\mathrm{B}$ and C. It is possible that the signal might represent former settlement across these areas.

The sherds collected as part of the survey range in date between the Chalcolithic and the early modern periods, with the majority of the material recorded consisting of coarse wares. An assumption inherent in our collection strategy, which targeted bases, rims and handles, is that the number of feature sherds would be in proportion to the number of uncollected body sherds. A complete fabric and form series was created on site by Eniko Hudak and is available for consultation on site at Çatalhöyük. The pottery collected was fully quantified using the standard measures of sherd count, weight and estimated vessel equivalents (EVEs). Sherds were categorised into form types, and examples of each type were drawn. Following examination of fresh breaks, all the sherds in the assemblage were allocated to fabric groups using a set of alphanumeric fabric codes, for which representative typesherds were given detailed fabric descriptions; photographs are available online (Çatalhöyük Living Archive: http://catalhoyuk.stanford.edu).

Analysis of ceramics collected. Of the ceramics collected in the field, a total of 86 form types was identified by Hudak. Eighty different fabrics were grouped into broad fabric families - coarse wares, fine wares, glazed pottery 


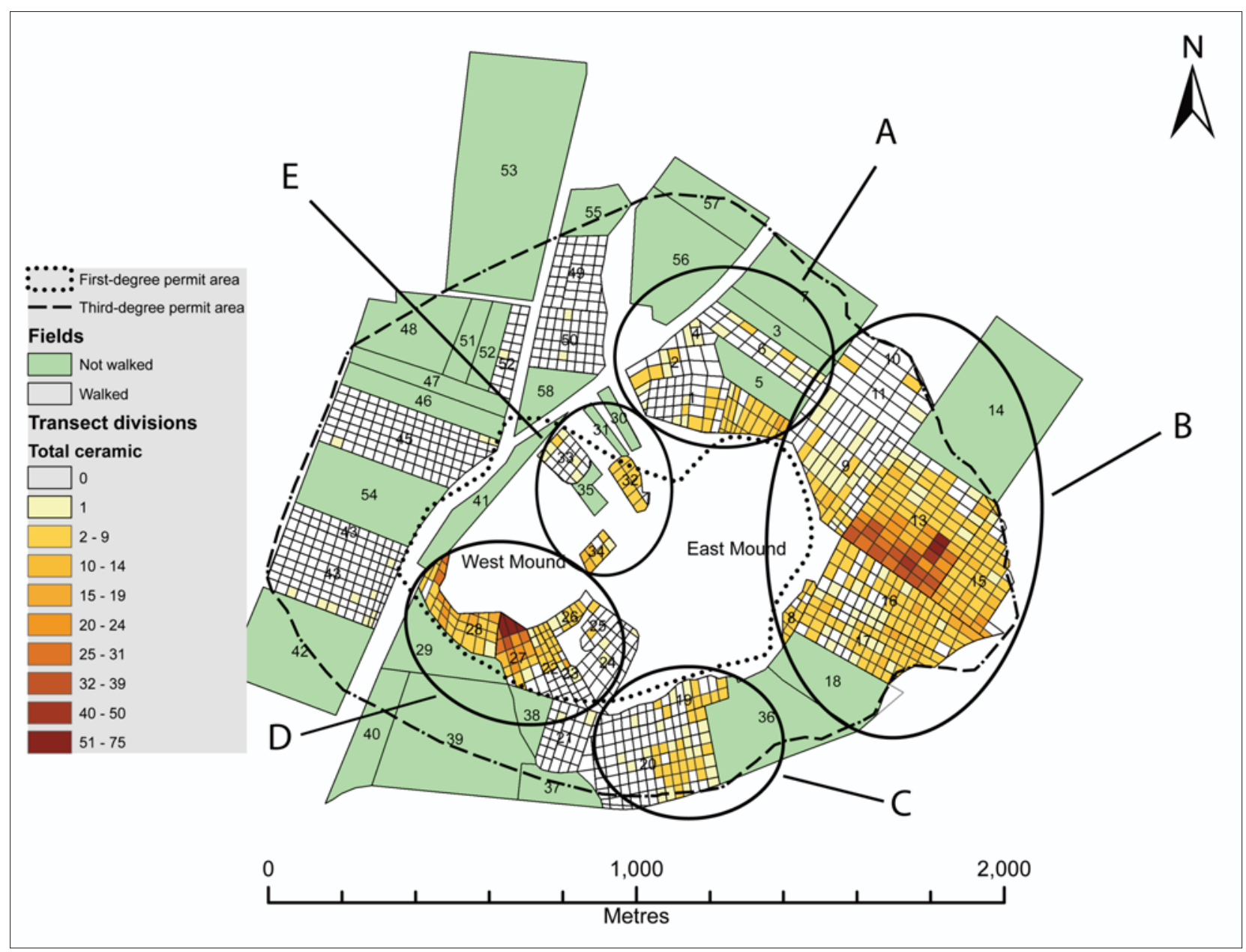

Fig. 6. Areas of high ceramic concentrations (M. Jackson, S. Moore, T. Sutcliffe, A. Turner).

and prehistoric pottery. Individual sherds were identified by a unique code: field number. transect line. transect division/sherd number within the division (for example 013.05.07/s1).

The forms and fabric profiles of cluster $\mathrm{ABC}$ reveal a small proportion of prehistoric pottery (limited to three collected sherds) and a significant volume of material from the first and second millennia AD (220 collected sherds; the total sherd count within the ABC cluster is 1,398). The prehistoric pottery includes a handmade, burnished holemouth jar with everted rim; its fabric has a grey core and margins, and a red surface (001.17.01/s1; Ingmar Franz, personal communication July 2015).

There is evidence for late Hellenistic ware in this area, as shown on figure 7 . The evidence for occupation in this period, represented by this group of ceramics, might be related to the Hellenistic phases of the site currently under excavation in the TPC Area of the East Mound (Filipowicz et al. 2014). Examples of Roman-period ceramics are shown on figure 8.

Six sherds in cluster $\mathrm{ABC}$ can be positively identified as post-medieval. Mostly from area B, these are from green-glazed vessels and are shown on figure 9 (001.12.03/s1, 009.11.07/s1, 001.16.02/s2, 013.05.07/s2, 013.06.07/s1, 015.03.01/s1).

Coarse ware is the most common fabric of the sherds of the ABC assemblage. The coarse wares are divided into four fabric families: cream-surfaced coarse wares; coarse micaceous wares; coarse reduced wares; and coarse oxidised wares. The cream surface appears rather like a slip but may be the result of the effects of firing rather than the application of a slip. Fabric reference photos are presented in table 1 .

Whilst a wide range of fabrics is represented within cluster ABC, cream-surfaced coarse wares dominate the assemblage. The most common forms for the creamsurfaced coarse wares are wheel-turned storage jar forms, either with outward-turned rims (fig. 10) or handles attached to the rim (fig. 11). The pale surface colour is characteristic and contrasts with the darker colour of the core of these coarse-ware sherds (figs 10, 11).

The most common fabric in the assemblage from the $\mathrm{ABC}$ area is CW01 (shown as the fabric reference for the cream-surfaced coarse ware in table 1). CW01 is a hard 


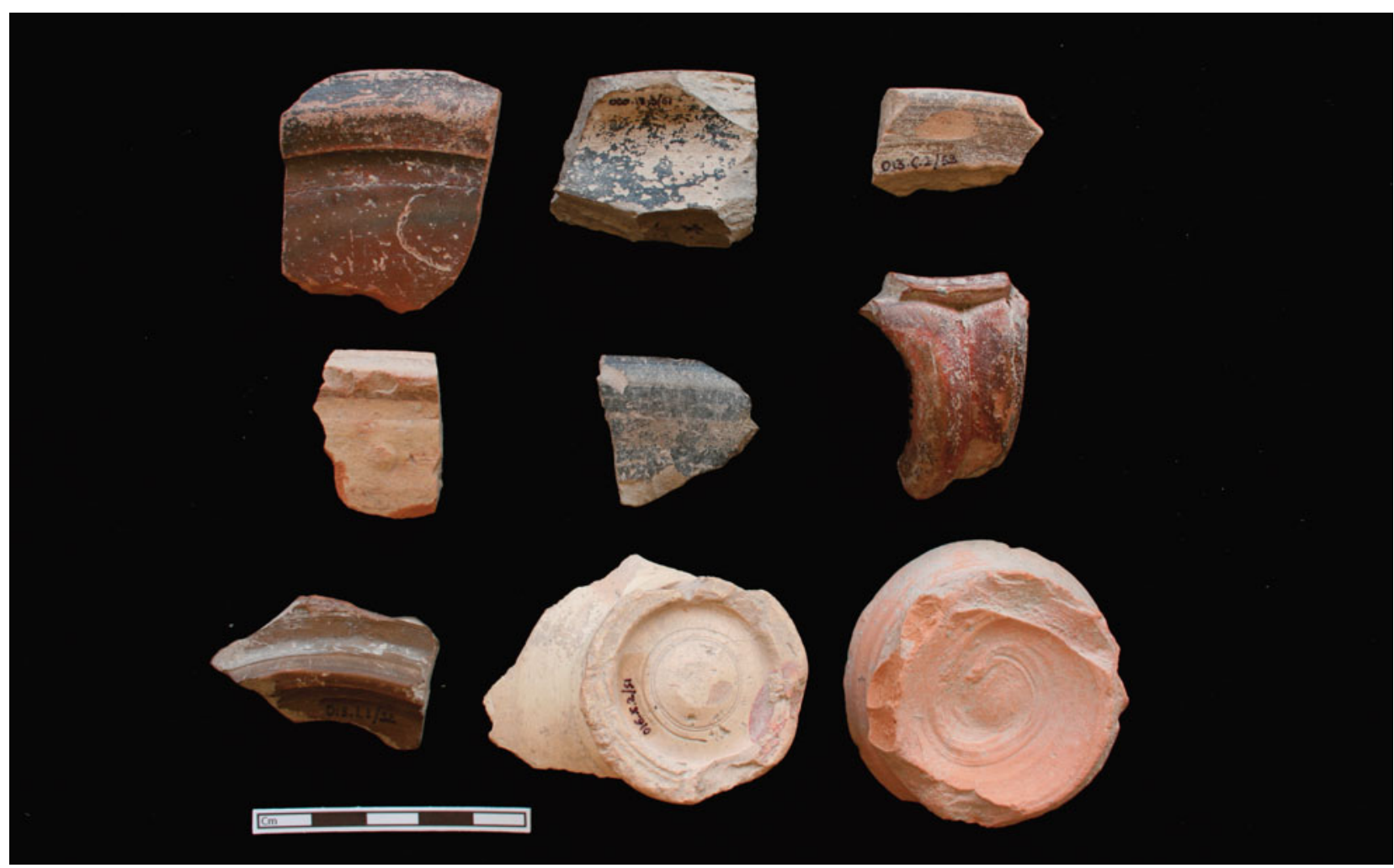

Fig. 7. Late Hellenistic fine wares. Top row: 013.05.07/s1, 020.13.03/s1, 013.06.02/s3; middle row: 013.04.05/s1, 013.01.03/s2, 001.14.02/s1; bottom row: 013.01.01/s2, 016.05.02/s1, 013.02.01/s4 (S. Moore).

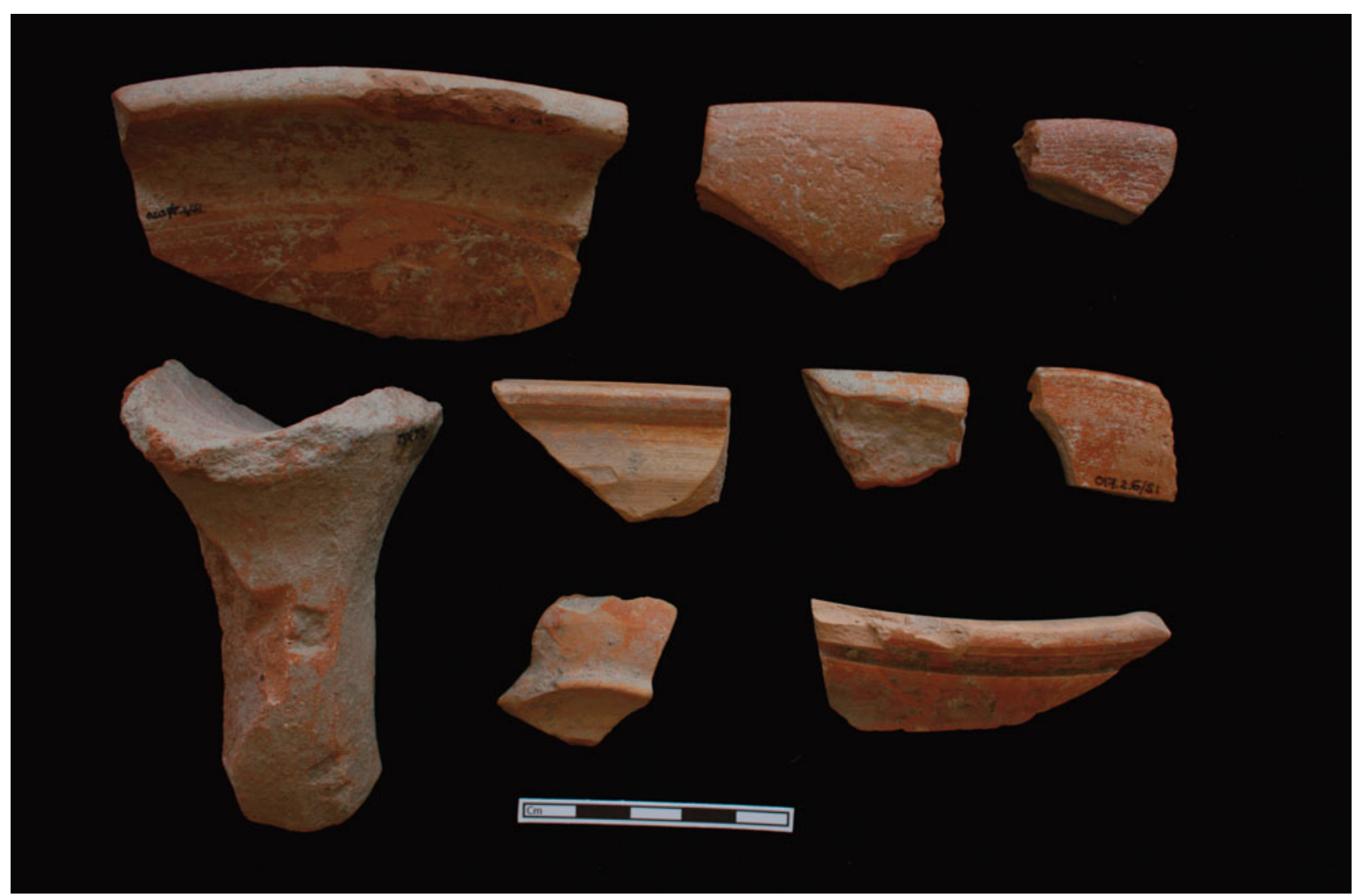

Fig. 8. Roman and late antique ceramics. Top row: 020.08.02/s1, 017.04.13/s2, 013.01.05/s2; middle row: 013.02.07/s2 (late Roman amphora handle), 015.07.02/s2, 013.01.06/s3, 017.02.06/s1; bottom row: 013.03.05/s4, 013.05.01/s4 (S. Moore). 


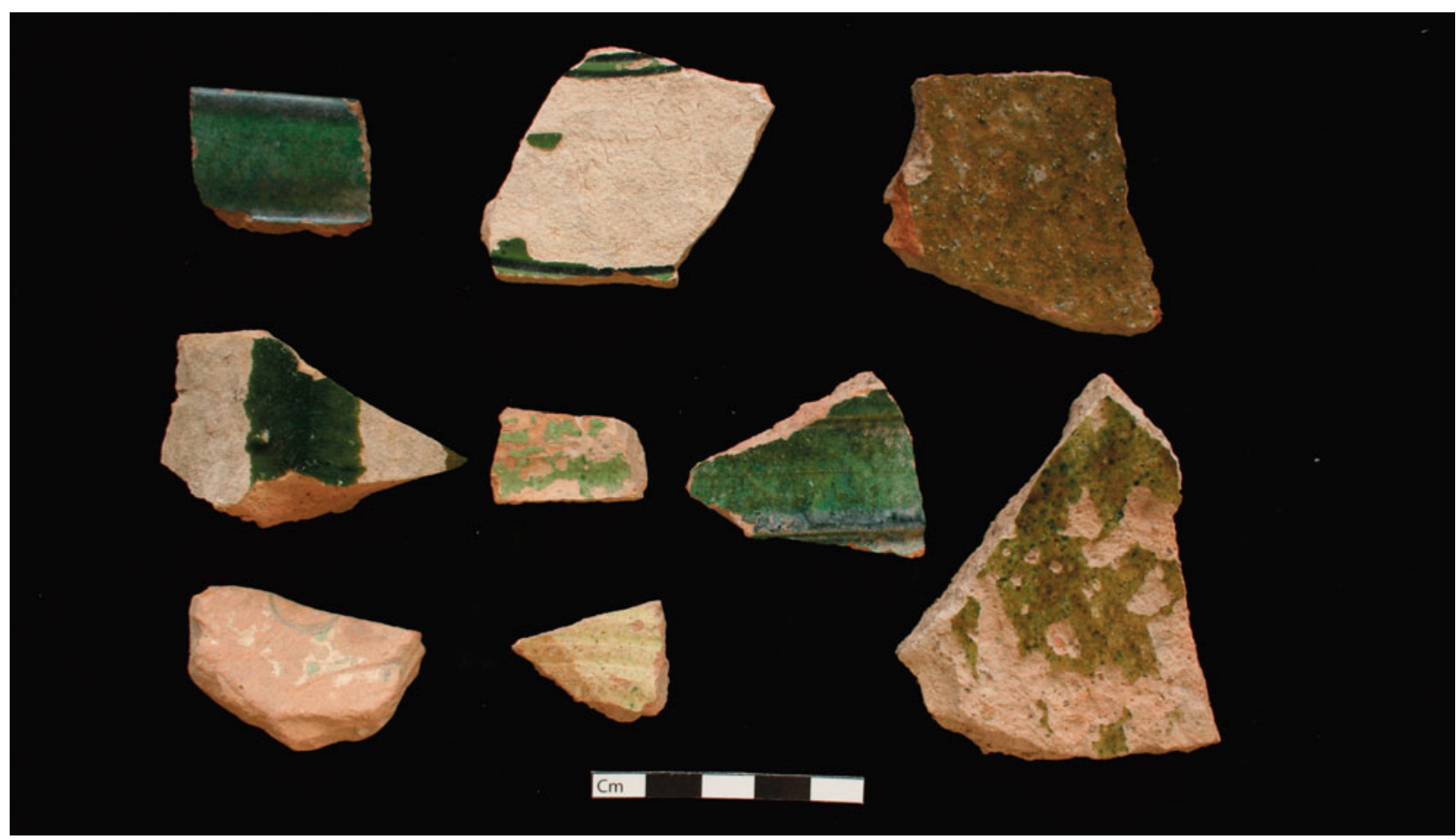

Fig. 9. Glazed wares. Top row: 001.12.03/s1, 035.02.03/s1, 034.01.01/s2; middle row: 034.01.01/s1, 009.11.07/s1, 001.16.02/s2; bottom row: 013.05.07/s2, 013.06.07.s1, 015.03.01/s1 (S. Moore).

Ware

Treatment and fabric description

Cream-surfaced The fabrics in this group all have a cream/yellow-coloured surface which coarse wares may be a slip, but appears more likely to be a result of firing conditions. The fabrics are usually hard and sand tempered, to varying extents, and range in colour from brick-red to grey. Possibly local (or nearby) products.

Coarse micaceous Coarse micaceous wares are characterised by a high mica content, either wares in the fabric or in the slip. These are hard fabrics in shades of red, with a variety of inclusions.
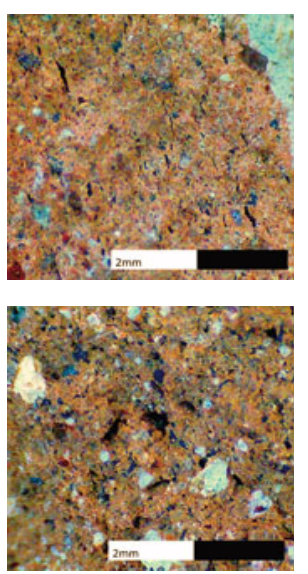

Coarse reduced Reduced fabrics.

wares

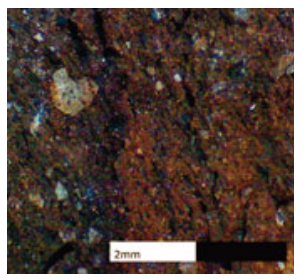

Coarse oxidised Oxidised fabrics, usually without any surface treatment. wares

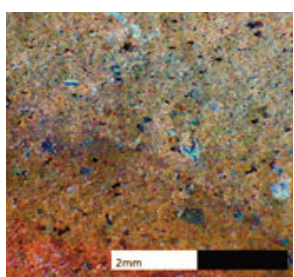

Table 1. Coarse-ware fabric treatments (fabric descriptions by E. Hudak; photographs by S. Moore). 


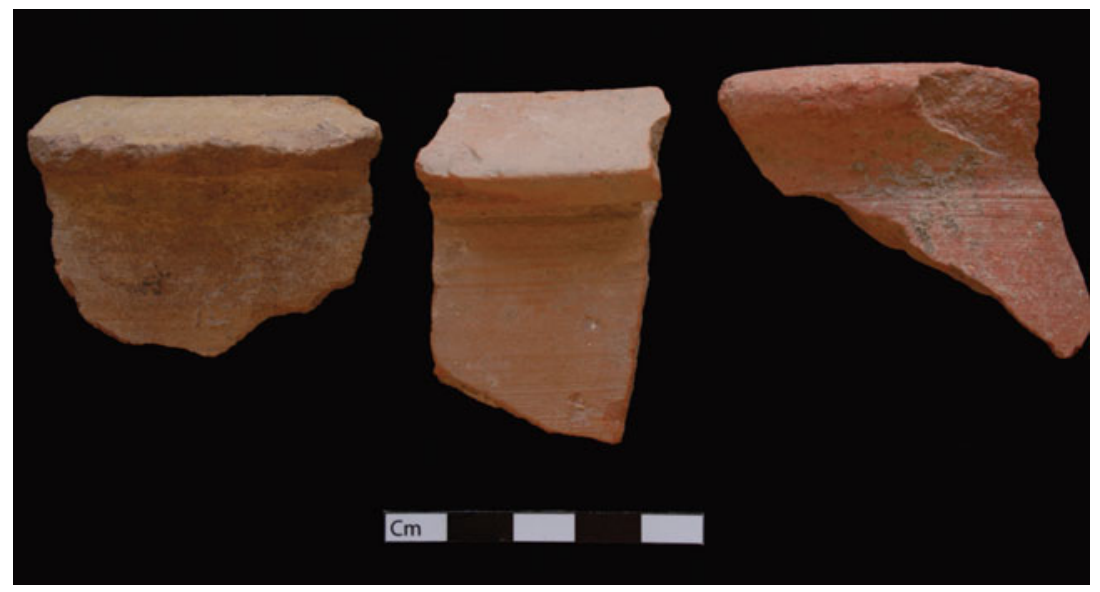

Fig. 10. Cream-surfaced coarse ware wheel-turned storage jar forms with outward-turned rims: 013.03.04/s2, 015.11.02/s1, 013.01.05/s1 (S. Moore).

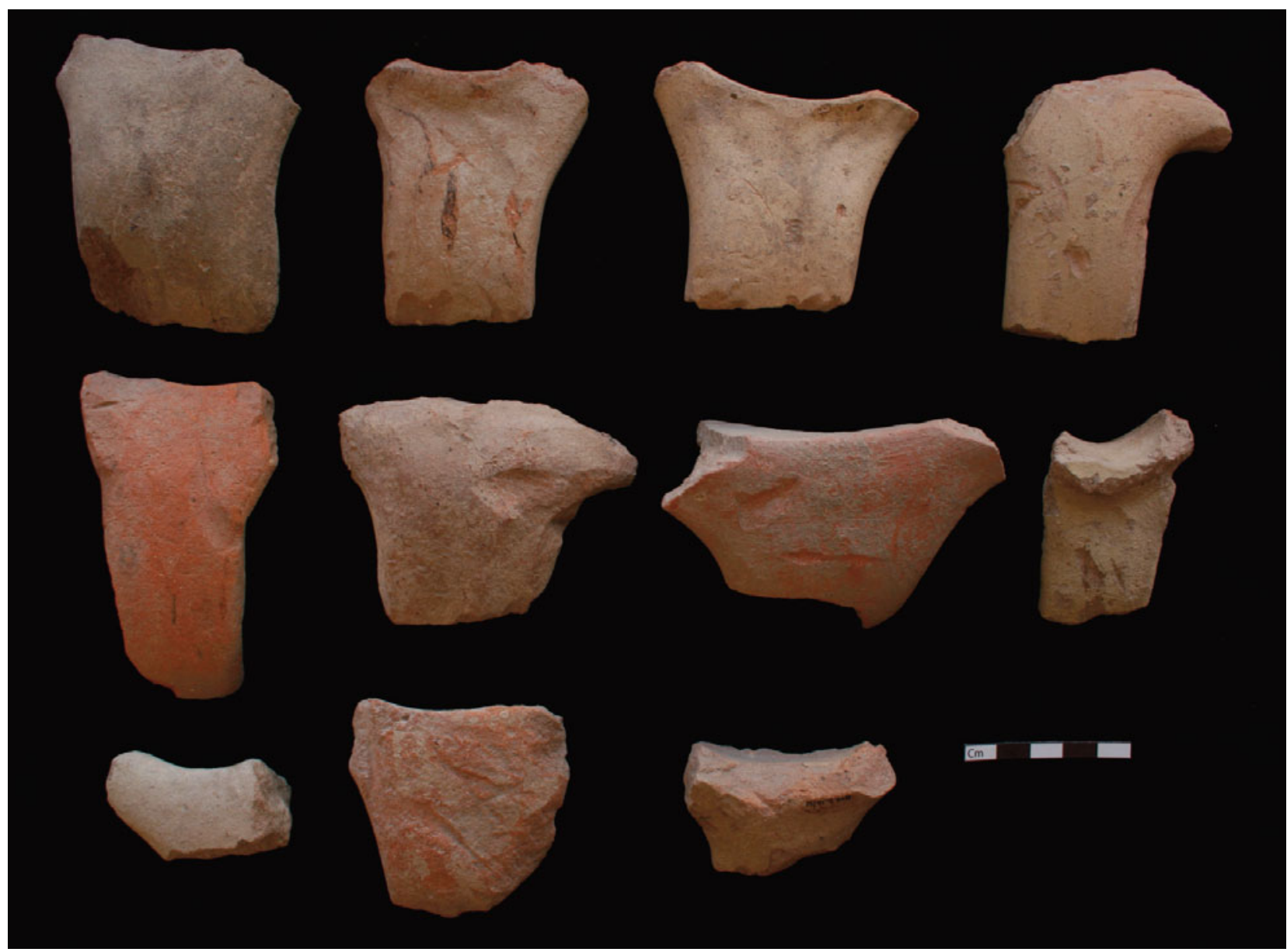

Fig. 11. Cream-surfaced coarse ware wheel-turned storage jar forms with handles attached to the rim. Top row: 013.02.06/s2, 017.01.04/s1, 016.16.04/s2, 020.08.03/s2; middle row: 017.04.10/s1, 001.13.01/s1, 015.05.02/s2, 016.12.02/s2; bottom row: 012.05.02/s1, 015.07.04/s1, 017.02.12/s1 (S. Moore).

fabric with a powdery feel and fracture, a pale brick-red core and cream surface. Inclusions are poorly sorted, $10 \%$, $0.1-0.25 \mathrm{~mm}$ sized, angular grey particles. The sherds containe sparse mica and very sparse red angular inclusions ca $0.25 \mathrm{~mm}$. The CW01 group appears to equate to Çatalhöyük coarse ware 4 , identified by Jonathan Last (1996: 148).
Given the inherent difficulty in assigning a chronological period to locally produced coarse wares, the chronology of fabric CW01 is by no means certain. There are examples of local coarse wares with cream surfaces from the excavation of the kilns which belong to the late Hellenistic to early Roman period (see below); given also the spread of Hellenistic to early Roman fine wares in 
cluster B, we can reasonably propose that some of these cream-surfaced sherds are from the Hellenistic to early Roman period. Among the CW01 category are a number of sherds from hand-turned pots which may date from the early to mid-second millennium $\mathrm{AD}$ : for example 013.03.02/s1, a hand-turned dish with a plain out-sloping rim, a smoothed interior and cream surface on both the interior and exterior. Without comparanda from securely stratified deposits, the proposed date of these sherds is very much a preliminary suggestion; however, the group of hand-turned pots is significantly different from the other cream-surfaced wares found in the two Hellenistic to early Roman kilns.

Coarse cooking sherds from the ABC area (fig. 12) may also date from the second millennium $\mathrm{AD}$, including: plain out-sloping rim $013.01 .03 / \mathrm{s} 3$, which is oxidised on the outside and reduced on the interior; flat strap handle $001.10 .02 / \mathrm{s} 1$; and base 013.06.03/s2. Table 2 and figure 13 summarise the composition of the assemblage from the $\mathrm{ABC}$ area by fabric.

The table wares shown on figure 7 and the storage vessels and locally produced coarse wares shown on figures 10 and 11 all suggest that the assemblage retrieved from the $\mathrm{ABC}$ area derived from domestic occupation. If we factor in the reduced visibility in a number of fields surrounding cluster A, the ceramic counts grade from a high central concentration to lower sherd counts at the edges. The density of the scatter at its centre, east of the East Mound, is a reasonable proxy for the location of a settlement, while the lower density areas surrounding may be a halo effect produced by land-management practices such as fertilisation using refuse which included ceramics (following Bintliff, Sbonias 2000: 246). Considering the extent to which the landscape is intensively ploughed, the defined nature of these ceramic scatters supports the interpretation that the ceramics in cluster $\mathrm{ABC}$ derive from settlement in the Hellenistic period and later.

The ground has been so intensively agriculturally reworked that it is unlikely that any further archaeological evidence for settlement exists above the alluvial layer in the zone immediately surrounding the mounds. No ceramics were located on the western side of the road (the line of a previous main north to south channel of the Çarşamba river, shown on fig. 3) in fields walked between numbers 40 and 54. This is a striking difference from the eastern side of the old course of the Çarşamba river, with its two Neolithic tells and long history of reuse and resettlement, partly evidenced by the ceramic scatters. This might be a product of taphonomic processes which we cannot account for, but it is equally possible that the absence of sherds is a result of a lack of settlement on the other side of the old course of the river which approximates to the current course of the road.

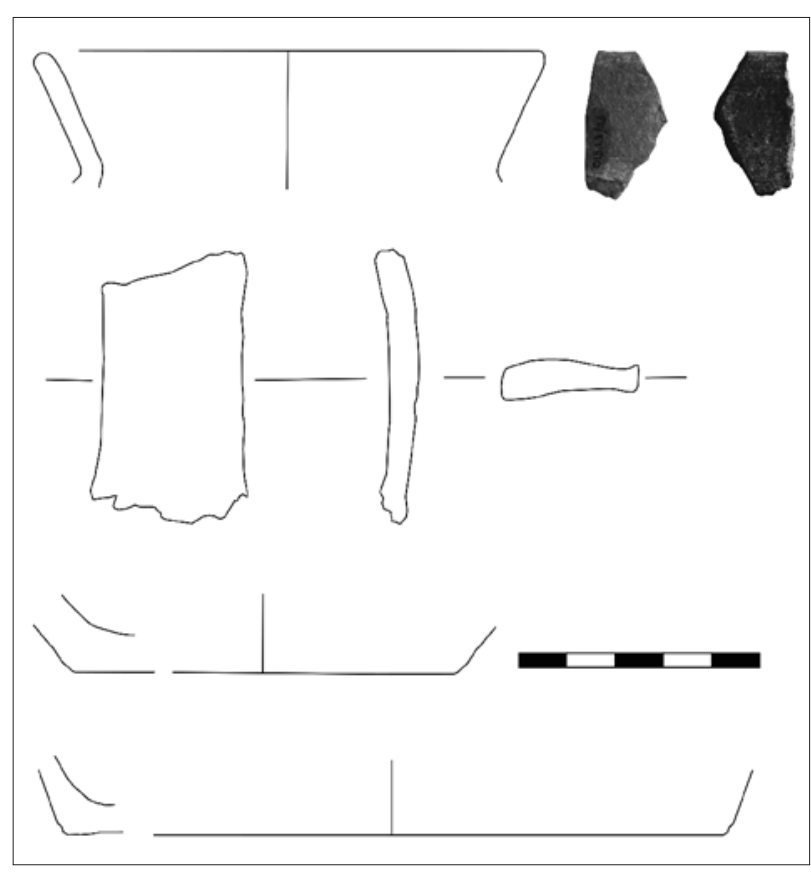

Fig. 12. Plain out-sloping rim showing oxidised exterior and reduced interior (013.01.03/s3), flat strap handle (001.10.02/s1) and two bases (001.10.02/s1 and 013.06.03/s2) (S. Moore).

Fields located on the slope of the West Mound produced a very different assemblage from those acquired from the other areas. The ceramic sherds positively identified as Neolithic and Chalcolithic were found mostly in cluster D, notably in fields 27 and 28 located south of the West Mound. Interestingly, significant amounts of tegulae were also recorded by the field-walkers in cluster D (table 3 presents the quantification of the ceramic types collected from area D and fig. 14 presents a graph of the data presented in table 3 ). The Neolithic/Chalcolithic pottery in cluster D is decorated with painted red/brown lines. The most common forms were plain rims (R03) and plain outward-turning rims (R01), similar to the pottery from the latest Neolithic phase of the site present on the West Mound (Franz, Ostaptchouk 2012: 103-08). Illustrations of the two key forms are presented in figures 15 and 16 . The alluvial layer which seals the prehistoric contexts in the other survey areas did not cover the high ground of the West Mound. The West Mound visibly slopes away to the alluvial plain beyond the limit of the fence, suggesting that the tell itself extends beyond the official boundary given as the first-degree permit limit (fig. 2) and marked by a fence on the ground. This conclusion is supported by the density of the pottery scatter and the shape of the fields in area $\mathrm{D}$, which radiate out from the mound, conforming to the topography of the landscape. A similar situation on the southeastern side of the East Mound explains prehistoric material recovered from field 8 (figs 6, 15). 


\begin{tabular}{lcccccc} 
Fabric type & $S C$ & SC $\%$ & Weight $(g)$ & Weight \% & EVE & EVE\% \\
\hline Glazed wares & 5 & 2.43 & 73 & 1.03 & 4 & 0.24 \\
Cream-surfaced coarse wares & 102 & 49.51 & 4,515 & 63.70 & 852 & 50.12 \\
Coarse micaceous wares & 7 & 3.40 & 207 & 2.92 & 36 & 2.12 \\
Coarse reduced wares & 22 & 10.68 & 171 & 2.41 & 104 & 6.12 \\
Coarse oxidised wares & 25 & 12.14 & 1,407 & 19.85 & 270 & 15.87 \\
Fine wares & 28 & 13.59 & 519 & 7.32 & 358 & 21.06 \\
Prehistoric pottery & 14 & 6.79 & 139 & 1.96 & 19 & 1.12 \\
Unassigned wares & 3 & 1.46 & 57 & 0.81 & 57 & 3.35 \\
Total & 206 & 100 & 7,088 & 100 & 1,700 & 100
\end{tabular}

Table 2. Quantification of fabric types in cluster $A B C(S C=$ sherd count; EVE = estimated vessel equivalent) (E. Hudak, S. Moore).

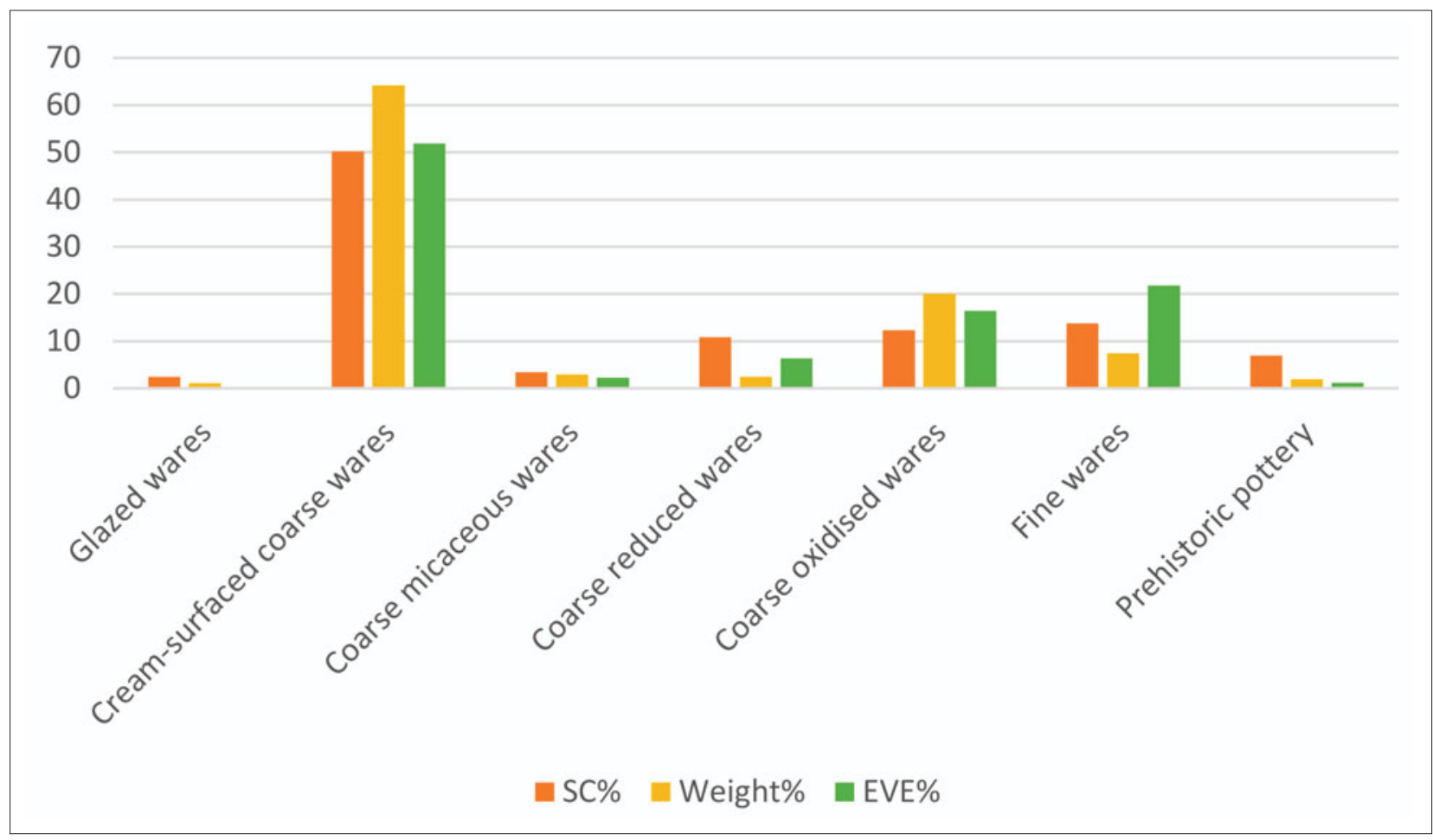

Fig. 13. Quantification of fabric types in cluster $A B C(S C=$ sherd count; EVE = estimated vessel equivalent) $(E$. Hudak, S. Moore).

A zoomorphic spout (027.02.01/s1) was recovered from south of the West Mound, and is shown in figure 17. A reasonable quantity of tegulae was present within area D (fig. 6), and, in the absence of other historic-period pottery, it seems plausible that the tiles found in this area are not indicative of buildings, but, rather, are of the type used to line Roman burials elsewhere on the mound (Moore, Jackson 2014: 604). The presence of these tiles in an area with little other later ceramic evidence suggests that the first-millennium AD cemetery may have extended at least to the limit of the West Mound, if not into the area between the mounds.

Very little pottery was collected from area E, lying between the mounds; the only sherds collected were three glazed-ware sherds (fig. 9 top row: 035.02.03/s1, 034.01.01/s2, middle row: 034.01.01/s1). Given the presence of glazed wares and the absence of any other kind of pottery except tile in this area, it is possible that the glazed wares in this area are connected to activity at the site of the current farmhouse located between the mounds. 


\begin{tabular}{lcccccc} 
Fabric type & $S C$ & SC $\%$ & Weight $(g)$ & Weight $\%$ & Eve & EVE\% \\
\hline Glazed wares & 0 & 0 & 0 & 0 & 0 & 0 \\
Cream-surfaced coarse wares & 2 & 3.33 & 81 & 11.36 & 8 & 9.09 \\
Coarse micaceous wares & 0 & 0 & 0 & 0 & 0 & 0 \\
Coarse reduced wares & 0 & 0 & 0 & 0 & 0 & 0 \\
Coarse oxidised wares & 0 & 0 & 0 & 0 & 0 & 0 \\
Fine wares & 0 & 0 & 0 & 0 & 0 & 0 \\
Prehistoric pottery & 58 & 96.67 & 632 & 88.64 & 80 & 90.91 \\
Total & 60 & 100 & 713 & 100 & 88 & 100
\end{tabular}

Table 3. Quantification of fabric types in cluster D (SC $=$ sherd count; $E V E=$ estimated vessel equivalent) (E. Hudak, S. Moore).

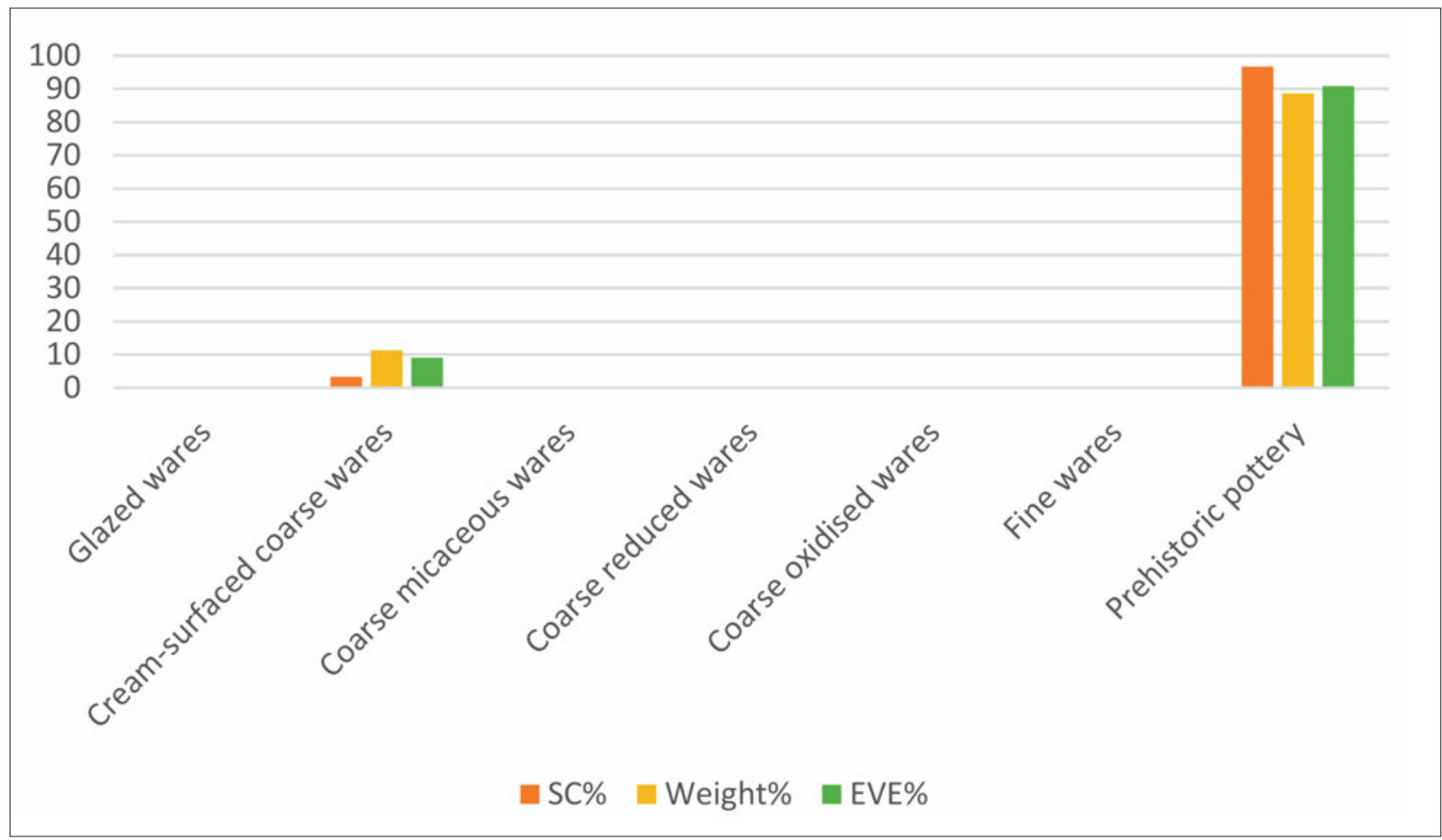

Fig. 14. Quantification of fabric types in cluster D (SC = sherd count; EVE = estimated vessel equivalent) (E. Hudak, S. Moore).

\section{Ceramic production at historic-period Çatalhöyük?}

A stratified type series gained through excavation is an important tool for establishing the chronology of ceramics collected from surface survey in the same locality. Evidence to corroborate the chronology of the material collected on the surface around Çatalhöyük is, unfortunately, somewhat limited, since the excavated material of the later phases on the site itself is characterised primarily by burials furnished with fine wares and glass vessels rather than the coarse-ware ceramics that dominate the assemblage collected on the survey. During the year-2000 season, however, two kilns (identified here and in the
Çatalhöyük archive as the East Kiln and the West Kiln) were revealed during the construction of the seminar room of the Çatalhöyük dig house, to the northwest of the East Mound. In addition, during the 2002 season, one circular kiln (Feature 996) and four rectangular kilns (Feature 991) were excavated in the TP Area and given a terminus ante quem of the late Hellenistic to early Roman period through preliminary analysis of the pottery (Czerniak et al. 2002).

Analysis of the photographs taken during excavation of the East and West Kilns in 2000 (fig. 18) reveals that both structures were light-bulb shaped in plan and had chambers of approximately $2 \mathrm{~m}$ in diameter. Ceramics and 


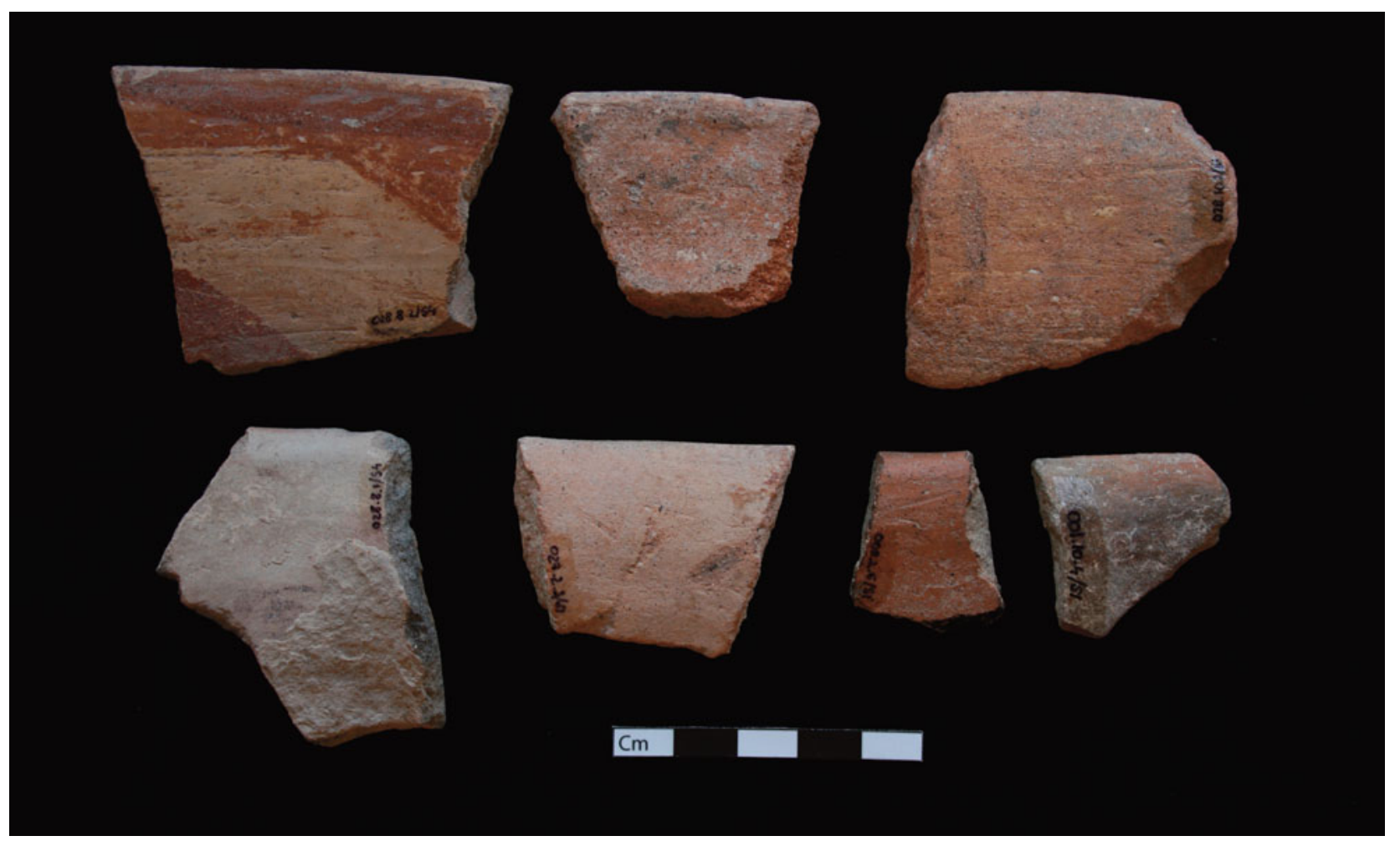

Fig. 15. Examples of prehistoric form rim 1. Top row: 028.08.02/s4, 028.08.01/s5, 028.10.02/s1; bottom row: 0128.08.01/s4, 027.02.03/s1, 008.02.05/s1, 001.10.04/s1 (S. Moore).

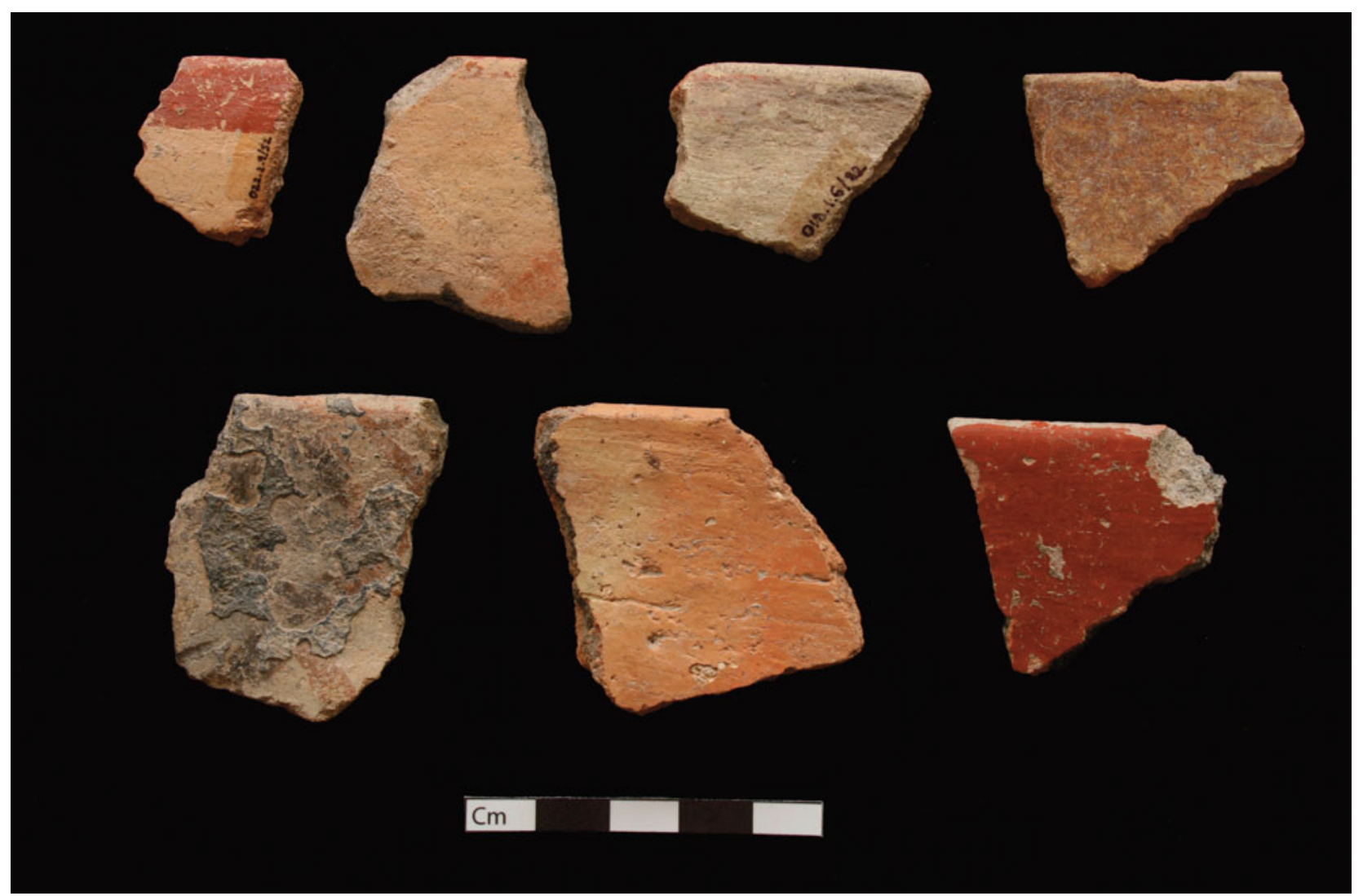

Fig. 16. Examples of prehistoric form rim 3. Top row: 022.02.09/s2, 028.09.01/s1, 013.01.06/s2, 028.06.01/s1; bottom row: 013.01.02/s6, 028.07.01/s1, 001.17.02/s1 (S. Moore). 


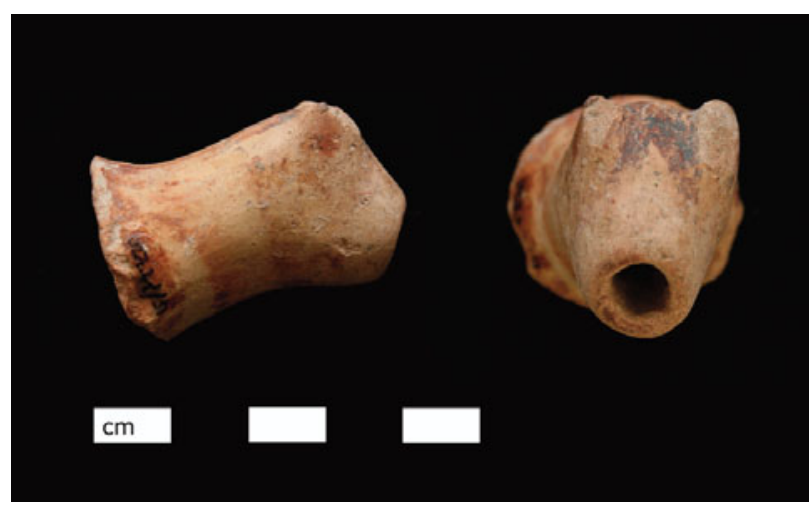

Fig. 17. Zoomorphic spout: 027.02.01/s1 (S. Moore).

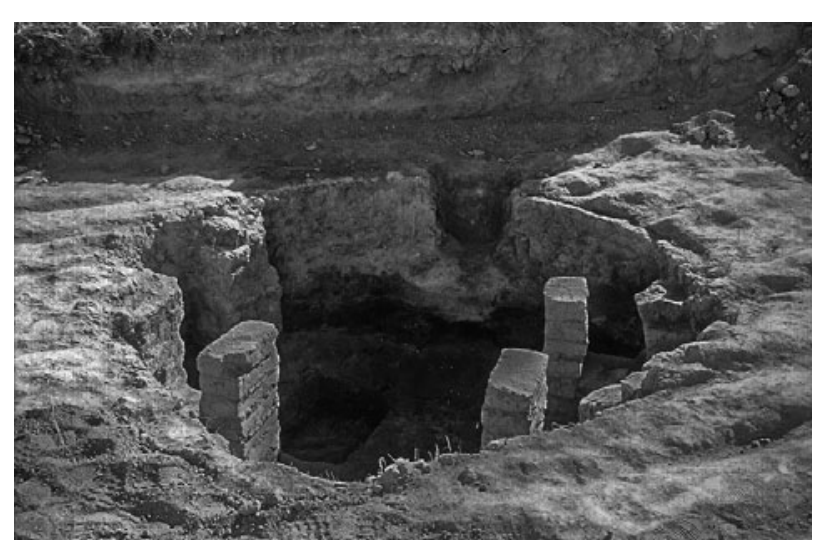

Fig. 18. Photograph of kiln from the Çatalhöyük archive (photographer unknown).

tiles were recovered from both kilns. A sample of the original assemblage was kept and is illustrated in figures 19 (East Kiln) and 20 (West Kiln). The material excavated from the East and West Kilns consists of a variety of household vessels, including cooking pots, plain wares and fine terra sigillata wares dating to the Hellenistic to early Roman period. Illustrations of rims and bases from the sample contained in the archive are shown in figures 21 (West Kiln) and 22 (East Kiln).

Four tiles were recovered from the West Kiln. The tiles are flat, $0.28 \mathrm{~m}^{2}$ and $0.04 \mathrm{~m}$ thick, and decorated diagonally from the corners by three fingers being drawn across the surface. They are similar to the flat square tiles (type 2) that were recovered from the post-Chalcolithic cemetery in the 4040 Area (for example burial F.1450: Moore, Jackson 2014: 604, fig. 32.4g, 608, 615). The vessels from the West Kiln include coarse, plain-ware material in a pale orange fabric. Certain coarse-ware sherds with orange fabric have fired to a cream-coloured surface (see fig. 20, top right, for an example which also has an impressed horizontal cordon). Wheelmade vessels with a cream-coloured surface are a distinctive feature of much of the material from the surface survey, so the presence of similar material in the kiln excavations is our main evidence for its chronology. Examples of handles with the irregular channelled form typical of handles 'pulled' by the potter are typical of the assemblage (fig. 20, right-hand side). The material also includes fragments of storage vessels and other coarse wares as well as several terra sigillata sherds with a fine orange fabric and red slip, including a dish with a low ring foot (fig. 21b), a thin-walled cup with a beaded rim (fig. 21c) and a base (fig. 21f). Examples of closed forms with very dark-brown/grey slip are present (see fig. 20, centre), as is at least one grey-slipped base (fig. 21e). Examples in a plain pale fabric include both open and closed forms (fig. 21a and 21d, respectively).

Material from the East Kiln includes plain coarse wares, either with a very pale fabric (fig. 22a) or a paleorange fabric - for example, a heavy plain bowl with an everted rim (fig 22e) - and buff wares including one fragment with grey slip (fig. 22c). Fragments of a terra sigillata bowl in a fine orange fabric with a red slip (fig. 22b) recall Sag Var1A161, dated stylistically from the first century AD to the first half of the second century $\mathrm{AD}$ (Poblome 1999: 352, fig. 16 no. 8). A single coarse grey cooking pot fragment with a thin vertical wall and everted rim was present (fig. 22d).

No evidence of wasters is present in the preserved sample. We cannot therefore directly link the ceramics found within the kilns to production on the site, and the range of different types, including coarse and fine, oxidised and reduced wares, suggests that the material may be refuse. The chronology of the material found within the chambers, however, may provide a terminus ante quem of the late Hellenistic to early Roman period for the use of the kilns.

\section{Discussion}

The data presented above demonstrate the potential of small-scale survey within government-defined site boundaries to contribute to our overall narratives of landscape. Under the permit system in place in 2013, our project could not have adopted the scope of wider regional surveys. By responding to the theoretical drive to approach landscapes holistically - that is viewing landscapes as perceived throughout time, landscape as a physical thing which shapes action and landscape as a collection of past human actions - we are able to consider the taphonomy of the landscape.

Comparison of satellite imagery and the late 20thcentury permit map shows that the basic morphology of the field boundaries on the Konya plain closest to Çatalhöyük has changed little over the last 25 years, although, as we can see from the satellite imagery, the content and subdivision of the fields has fluctuated in places over that time. Satellite imagery (available from Google Earth) also suggests that the modern field system, which predominates within our permit boundary, is representative of a large 


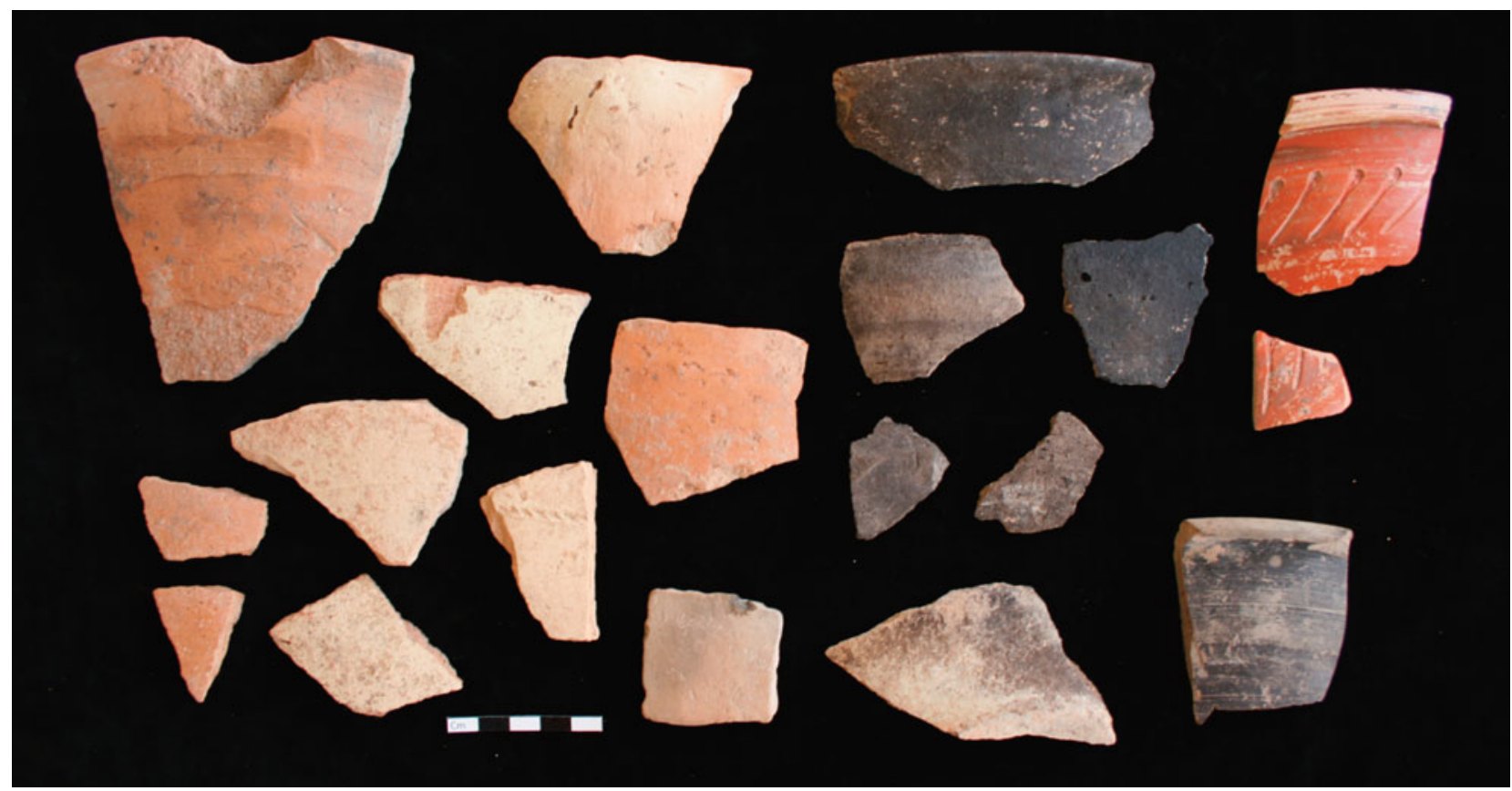

Fig. 19. Sample of ceramic material recovered from the East Kiln (S. Moore)

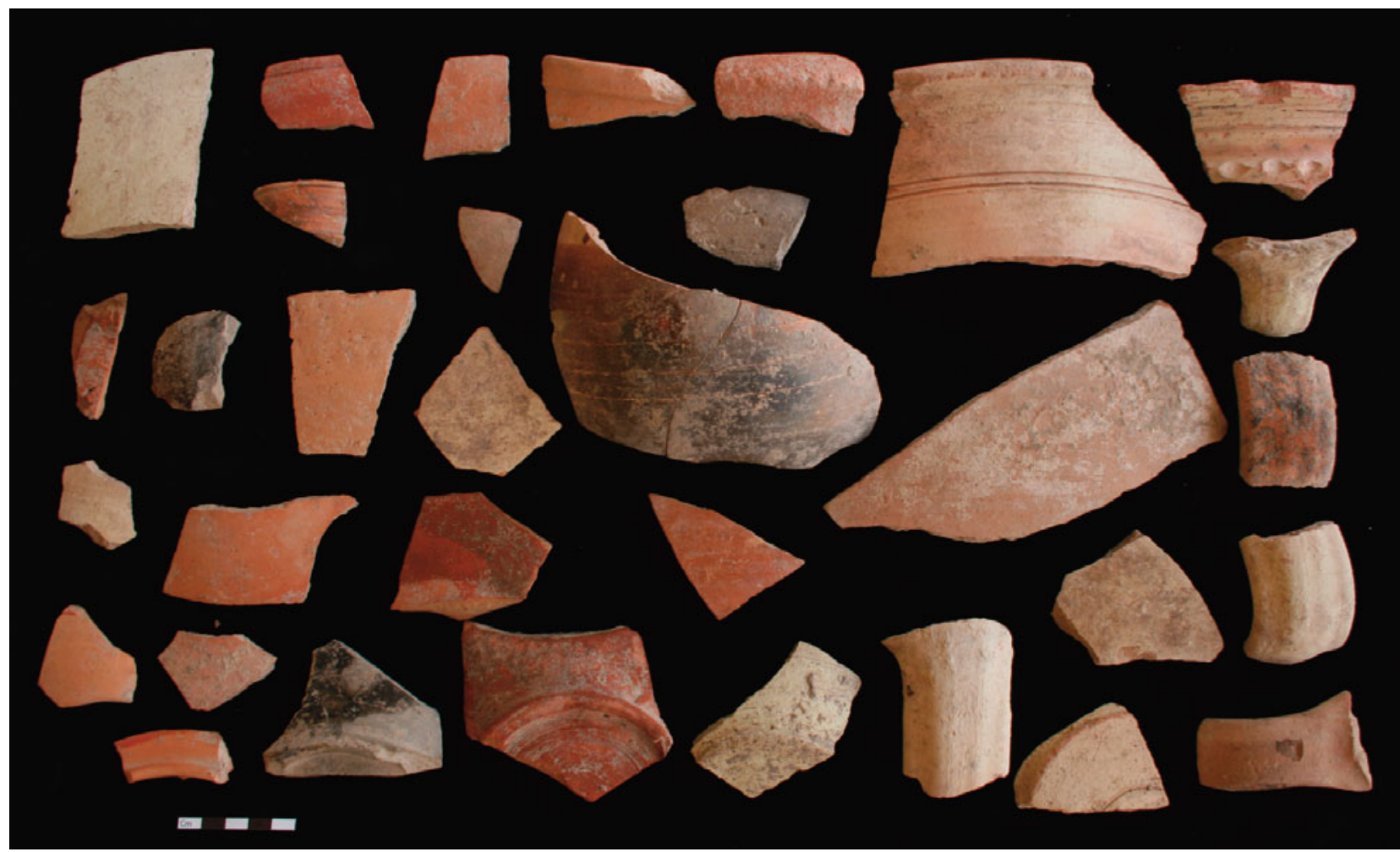

Fig. 20. Sample of ceramic material recovered from the West Kiln (S. Moore).

proportion of the plain, which is given over to crops such as sugar beet, wheat and corn. A wide-scale irrigation programme across the Konya plain was implemented in 1912, designed by Dutch engineers and implemented by a German firm (Hoeffelman 1913), and it is likely that the major transformation from traditional narrow irregular fields to the larger rectilinear fields we largely see today was begun after this time and is thus a change associated with the significant shift in irrigation practices.

Analysis of the satellite imagery freely available on Google Earth shows that the current rectilinear field system located in the immediate vicinity of Çatalhöyük is part of a 


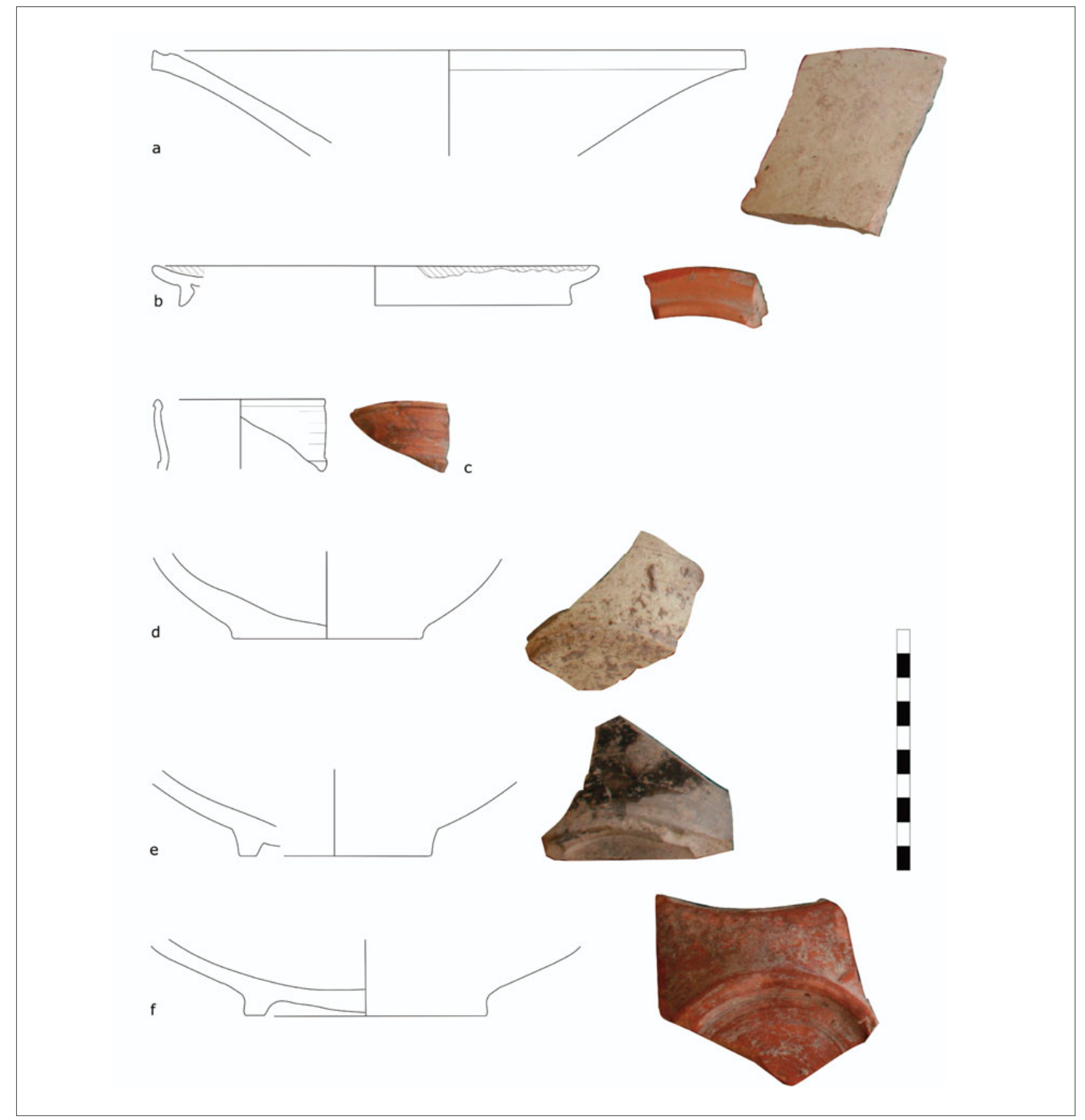

Fig. 21. Ceramic rims and bases from the West Kiln (S. Moore).

patchwork of similar areas of rectilinear field systems which spread out across the Konya plain. This complex network of gridded fields is not on a single alignment. Each set of fields has a slightly different morphology and field orientation; we could compare, for example, the orientation of the rectilinear fields around Çatalhöyük with those located $5 \mathrm{~km}$ to the northwest. The different patterns of these rectilinear systems suggest that, in the transformation of the landscape from narrow irregular fields to the current rectilinear arrangement, the new arrangement did not entirely replace the old and was implemented to respect existing roads and waterways. At the same time, the satellite imagery of the wider landscape appears to include areas of fields characterised by fields with complex networks of curving boundaries, for example that $8 \mathrm{~km}$ to the northeast of Çatalhöyük, that appear to belong to the morphologies of much older systems. Although we have not pinned down the precise timeframe of the transformation to the current rectilinear field system, we can talk with some accuracy about what happened and suggest likely reasons for the occurrence of the change: irrigation, centralised agricultural policy and mechanisation. It seems likely that the process of transformation is continuing. At one step removed from modernity, our data are still in focus. 


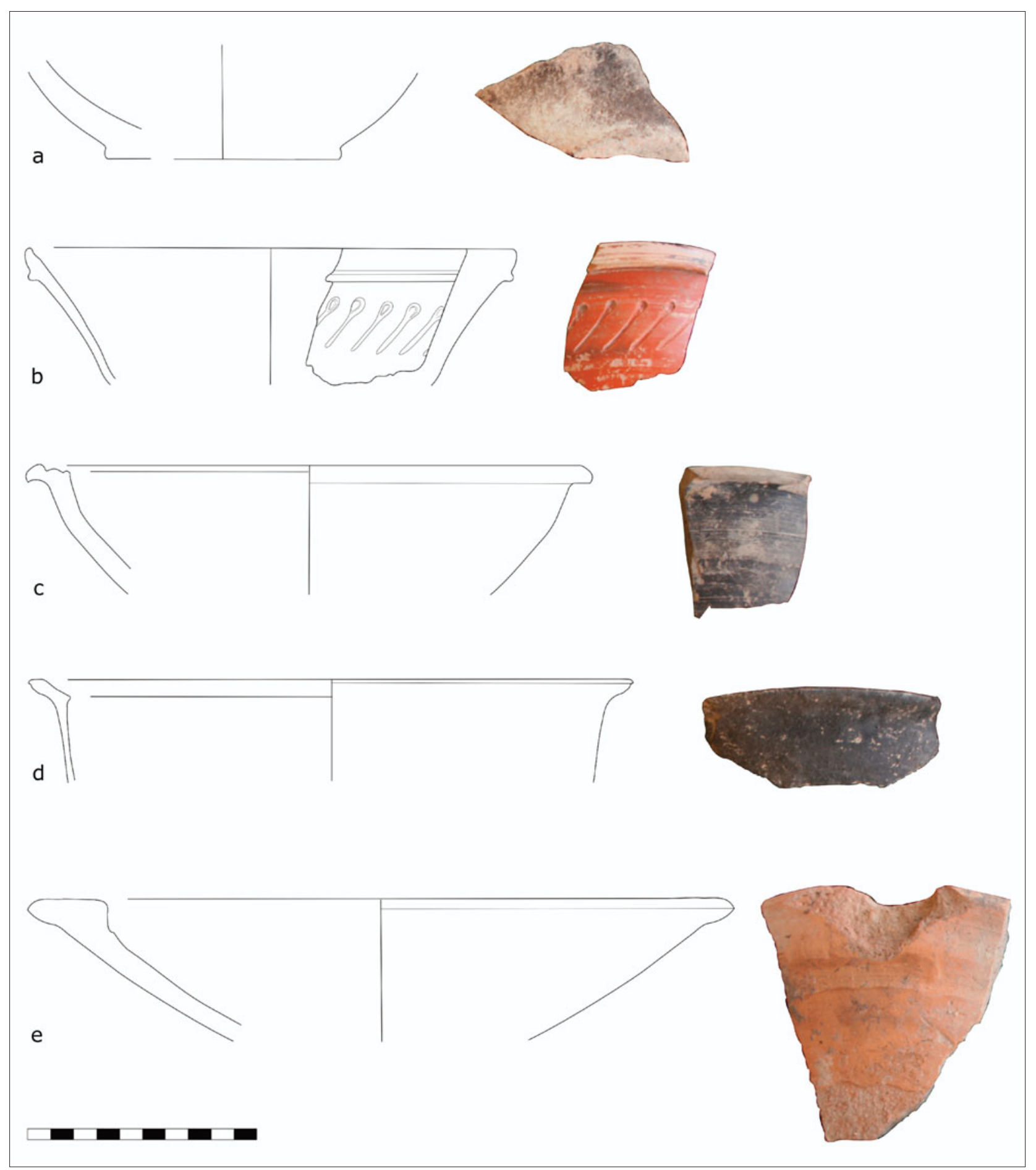

Fig. 22. Ceramic rims from the East Kiln (S. Moore).

During the late 20th century, Shankland recognised that local people invest meaning in mounds within their home environment: 'just as do the archaeologists, they possess a coherent sense of the past of the area' (1996: 354). The oral history recorded by Shankland is particularly valuable for understanding the recent past, which has been comparatively neglected while much earlier periods have dominated attention. Oral histories from local villagers have revealed these recent perspectives, but until now there have not been attempts to link them to the archaeological record; as Shankland commented in 1996, 'archaeologists' collective view of the world and its past epochs' is based on their own sifting, and ignores and overlooks 'much of the evidence of the past in the area which does not address their immediate enquiry' (1996: 354). For a holistic approach, such insights into more recent periods are necessarily considered as elements in the understanding of the continual taphonomy of landscape, rather 
than being used principally as a means by which existing populations can inform on the prehistoric past.

The farmhouse and orchard which are currently present between the mounds are associated with the strip fields which predate the modern rectilinear system. The taphonomy of this specific part of the landscape is probably tied to both topography and the curation of Çatalhöyük as an archaeological site. The old narrow irregular fields are preserved because large rectilinear fields would not fit neatly between the mound and could not be imposed over them due to the protected nature of the site.

There is little sign of any fields from the earlier system on the mounds themselves. While it might be argued that the mounds were less suitable for cultivation, for example because irrigation and ploughing might be more difficult here than on the alluvial plain, we must also consider interpretations of this situation which go beyond the functional. It is tempting to conclude that Çatalhöyük may have been considered unsuitable for cultivation because of its ancient past and especially its role as a place of burial. Shankland cites 'other sites' that feature in the wider modern local cosmology which includes the supernatural and the spirits of the deceased: 'Many of the larger mounds [in the Çatalhöyük area] are regarded as being protected by the previous inhabitants of the area' (1996: 355).

The farmhouse and the older fields located between the mounds represent a surviving example of the kind of farm that existed before the 20th-century landscape reorganisation. Indeed the few sherds of green-glazed pottery recovered from the associated fields suggest that the farmhouse site could have been in use for at least several hundred years. At two steps removed from the modern landscape, our data is less sharply in focus. The two different scales of evidence, the landscape between the mounds and the pottery found in loose association with the buildings, both work to illuminate the landscape in recent centuries at different levels of precision. At this resolution our data have become less clear and precise, but perhaps only because our investigations have not focused sufficiently on this time period.

The evidence available for the nature of land use is less clear as we go back in time. In the 1990s, the local people of nearby Küçükköy held that 'Greeks (Rum) used to possess fields in the area' before the population exchanges of the 1920s (Shankland 1996: 355). Their comments may be taken to suggest that, even 70 years later, members of the Turkish community made a connection between the land and the Christian populations who once worked it. While we cannot be sure which individual fields were worked by specific elements of the pre-exchange population, it is clear that the energy of these people would probably have been spent in the older field system that predates the imposition of the modern rectilinear agricul- tural fields in, most likely, a later part of the 20th century. This oral history is remarkably important for shedding light on the final phase of this older system of fields.

The inherent and complex stratigraphy within the boundaries of the earlier system of fields (preserved in the 1993 permit map, fig. 2, and marked in red on fig. 3) provides a potential record of the preservation of more ancient phases of the landscape. And yet, because of the nature of the data, our chronological categories for the wider landscape are more imprecise because, for now, we rely on relative chronologies for their interpretation. Innovative techniques, such as OSL dating pioneered recently for terraces (Kinnaird et al. 2017), might be applied to help refine the chronology of field boundaries, with the possibility of establishing absolute dates in areas such as the strip fields between the mounds at Çatalhöyük that have been protected by the designation of the archaeological site.

The relationship between the probable settlement indicated by the concentration of ceramics in areas A, B and $\mathrm{C}$ and the first- and second-millennium $\mathrm{AD}$ cemetery located on the prehistoric tells of the East and West Mounds is complex. The evidence for the settlement, for the industrial use of the site for the production of tegulae and/or for burial stretches across a time period from the Hellenistic to the present day. In terms of the relationship between first-millennium AD landscape use and the cemetery, one of the most important datasets is that of the count data indicating the concentration of tile sherds.

The scatter of tile across the surveyed area does not relate to a single archaeological deposition, but, rather, it can be taken as a representation of different types of land use. Tiles were used for a number of different purposes throughout the Roman and late antique periods, and, without collecting a representative sample of tile (any quantity of which would place unacceptable strain on the storage facilities on site), we are unable categorically to identify the function of the tiles present from their form. Tegulae were used to line Roman graves on site (for example Feature 1553 and Feature 1450: Moore, Jackson 2014), and may have been used to roof monumental buildings; they might also have been present as floor tiles or, for example, to line the walls of a bathhouse. However, where tile is present in an area devoid of high concentrations of any pottery other than prehistoric (for example in cluster D), the tile is likely to have been used as grave linings, and thus to represent the extension of the Roman cemetery. Figure 6 shows the cluster D concentration of tile extending to the physical limits of the West Mound, if not slightly beyond.

The tile in areas A, B and C is, however, unlikely to indicate the continuation of the cemetery. Rather - in combination with the other ceramics recorded there - it seems to represent evidence for settlement. There are high numbers of sherds of cream-surfaced coarse ware on the 
surface here (figs 6, 13); these are similar to the coarse wares excavated from the kilns. The cream-surfaced coarse ware vessels are usually associated with domestic contexts and may be distinguished from the finer types of ceramics, such as unguentaria, which are less visible in our survey material but found in higher concentrations in burials on the mounds (Moore, Jackson 2014). If we accept the ceramic scatter in areas $\mathrm{ABC}$ as indicative of settlement, it is likely that the associated tiles also come from a building (or buildings) rather than graves, particularly since a necropolis would usually be separated from a settlement in Roman times (Davies 1999: 148-49). These ceramic scatters are at some distance from the mounds, which seem to be the focus of the historic-period cemeteries.

Two marble architectural fragments (a capital and column base), which currently reside outside the guard's house at Çatalhöyük, were reportedly found in an area $500 \mathrm{~m}$ northeast of the East Mound. This location was drawn to our attention in 2012 by one of the site guards, Mustafa Tokyagsun. The fineness of the carving in stone imported to this part of the plain provides an indication of the existence of a monumental building of some significance (fig. 23). Both the capital and base show signs of reuse; their tops have been used as working surfaces.

A substantial quantity of architectural fragments, which appear to be spolia from monumental antique buildings, is reported within buildings at the nearby village of Küçükköy; it is, though, entirely possible that these originate from further afield. The people of Küçükköy have an oral tradition which recalls that they originate from a settlement - whose 'remains partly overlap with the site at Çatalhöyük' - called Eskiköy or 'old village' (Shankland 1996: 355). Given all this evidence, we suggest that the ceramics and tiles located during our survey may represent a related settlement, rather than an extension of the cemetery on the tells, and that a wider survey - including Küçükköy - would likely have revealed a more substantial pattern of settlement, of which we have identified one part only.
The sample of excavated well-contextualised graves from the historic-period cemeteries at Çatalhöyük includes approximately 210 individuals interred over a period of about 1,700 years, beginning in the first century AD. These graves are present in every excavated area of the site, on both the East and the West Mounds. As less than 10\% of the surface area of the mounds has been excavated and as the cemetery seems to extend across the whole surface of both mounds and potentially between them, and assuming that the density of burial remains more or less constant, we might conservatively estimate the total cemetery population of the mound at 2,000 individuals (with a significant margin for error). The density of burial will probably not have been consistent across the entire surface of both mounds, so our figure cannot be exact; however, a mortuary population of even half this size would indicate that, although we have identified a number of settlement locations in the immediate vicinity of the mound, the ceramic signals presented here cannot represent the entire settlement area from which the mortuary population originated. This suggests that, for at least part of its use-life as a cemetery, individuals were brought from across the wider landscape to be interred at this location. This indicates that, in contrast to the situation in the prehistoric period at Çatalhöyük when burials and houses were intimately related, for the period around two millennia ago there was a clear separation between the necropolis on the mounds and settlement on the lower ground below.

The visibility of cemeteries and tombs is an important feature of Roman cemeteries. Graves at the coastal cities of Elaiussa Sebaste and Korykos are prominent statements within the landscape (Herzfeld, Guyer 1930; Equini Schneider 1999). At Çatalhöyük, the mounds themselves provide this visibility, by lifting the cemetery above the plain and making it a reference point in the landscape associated with the dead. In using the site as a cemetery, routes and pathways between the plain and the mound would have been required, and these may have been routes main-

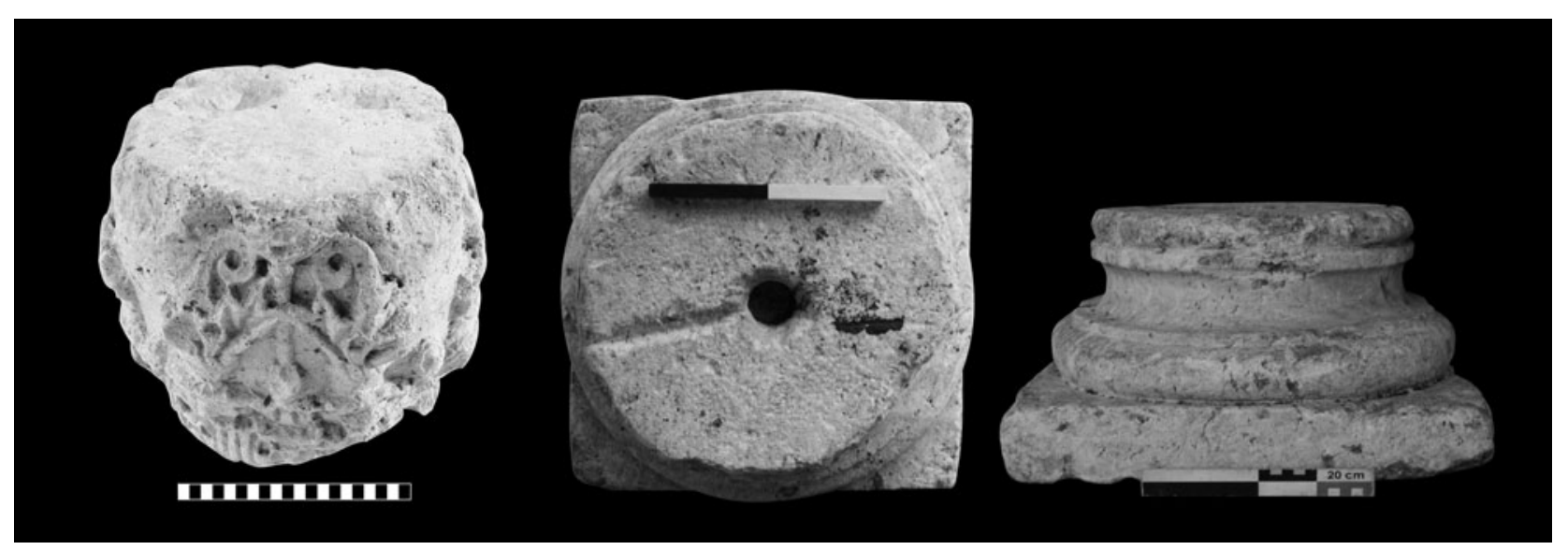

Fig. 23. Column capital and top and side views of column base (S. Moore). 
tained from previous periods, such as the route north along the old course of the Çarşamba river, the line of the current road to Küçükköy, or, heading in other directions, paths associated with the older field system with its inherent radial patterns.

At the early Christian site of Alahan, Emma Baysal and Hugh Elton have argued that the quality of seeing, rather than being seen, was the leading factor in deciding where to place the Hellenistic and late Roman tombs, and this may well be the case at other sites too (Baysal, Elton 2014). At Çatalhöyük, where we have little evidence of visible superstructure for the Roman graves, it may have been the view from the grave locations, as much as the view of the raised locations of the graves, that was a significant factor in determining to place the cemetery at this high location. Thus the landscape of the Roman cemetery at Çatalhöyük was formed from a combination of modes of perception, the physical nature of the place and various human actions (including settlement, burial, pottery production, farming) in both the Neolithic and Roman pasts.

The location is significant to every population group interred on the mound. Each community of practice selected the site as appropriate for burial, and cut graves into previously deposited material - graves, structures and midden - knowing that people had used the same site previously. These interactions with past communities will be discussed in greater detail elsewhere (Marciniak, Moore in preparation), but it is worth noting here that these interactions are all fundamental elements of the taphonomy of the landscape; each set of actions is contingent on the physical context set in train by preceding communities.

In the present we have multiple data sources which we use as proxies for different activities at different times. These sources are not altogether comparable and certainly do not represent the breadth of human activity in the environs of Çatalhöyük; rather, they work at different scales to illuminate past practices. The rather limited scope of our survey area as defined by the permit makes it necessary to acknowledge the importance of the wider context we have not attempted to examine. For example, the ancient volcano at Karadağ, north of Karaman, dominates the skyline viewed from Çatalhöyük, and 'beyond it one sees the great sweep of the snow-covered Taurus Mountains and towards the northeast the graceful twin cone of Hasan Dağ near Aksaray' (Mellaart 1962: 43 44). The mountain peaks of the region, which have always been a part of daily life and are visible from great distances, are elements of the wider topography that have been claimed and reclaimed in different ages (Jackson 2017).

The landscape of the immediate environs of Çatalhöyük, together with the cemetery which runs across both mounds and the kilns located on site all indicate that Çatalhöyük has had an extended, but discontinuous use-life beyond prehistory. Further detailed work on the excavated evidence and a substantial programme of radiocarbon dating will enable this picture to be examined in more detail (Marciniak, Moore in preparation). At this point, we suggest that discontinuous cemetery use is probable; it would be remarkable to find a cemetery which was continually in use for nearly two millennia. Thus, although Roman, Seljuk and Ottoman materials and graves have been identified, based on the current evidence, it is unlikely that there is also a Byzantine cemetery present (Kwiatkowska 2009; Moore, Jackson 2014: 606); the results of the ceramic and landscape survey presented here support the conclusion that there was discontinuous use of the cemetery.

The presence of a settlement east of the cemetery, the kilns on the northern slope of the East Mound and on the East Mound proper in the TP Area, the time frame of the cemetery, its relative size and the density of the burials all suggest that Çatalhöyük and its immediate environs went through periods of time when they were characterised by domestic and/or industrial use and periods of time when the area appears to have been primarily used as a cemetery. The potential presence of Roman monuments (indicated by the architectural fragments and the large quantity of spolia present in Küçükköy) suggests that a survey of the wider area - including Küçükköy - might well provide a more comprehensive context for first- and second-millennium AD Çatalhöyük.

\section{Conclusions}

Current theoretical approaches to landscape studies challenge us to consider concepts of place more broadly, moving away from asking questions primarily relevant to known sites in order to consider the experienced nature of place. This study has helped us to gain a clearer picture of life in the immediate environs of the site of Çatalhöyük over a long period from prehistory to the present, thereby making a new contribution to the study of Çatalhöyük as well as to understanding the Konya plain. In terms of the post-Chalcolithic contexts excavated at Çatalhöyük, we are better able to interpret the cemetery data from the mounds. Using the tile scatters between the mounds and lack of domestic pottery in the area as a proxy for Roman graves, we are better able to appreciate the extent of the cemetery. As with other Anatolian projects, the ceramic analysis has driven home the importance of the full publication of local coarse wares from rural sites. Such data are an essential element of analysis, and could eventually aid in identifying those places of the 'every day' which tend to be side-lined elements of landscape assemblages. The project has also highlighted the problem of using ceramics to identify periods for which ceramics are less common and indicated that, for these periods, the continued use of landscape may nevertheless be visible in other datasets. 
The retrogressive map analysis tells us that the mound influenced the morphology of the surrounding landscape and that the character of the field systems with their radial pattern was preserved as part of the local experience over a very long period of time. At the near end of our chronological telescope, analysis of the map and satellite data has revealed more about how the status of Çatalhöyük as a place protected by law in the 20th century has influenced the landscape, even before the site was recognised as a UNESCO World Heritage Site in 2012. The defined limits of the mounds have acted to preserve older farming practice into the 21 st century through continued use of the historic strip-field system and have actively influenced the creation of new boundaries between the neatly tessellated modern field system and the irregularly shaped earlier system.

If we take the archaeological definition of taphonomy to be the process of transformation which occurs after deposition, the taphonomy of landscape encompasses both natural and cultural processes which change the landscape. The interactions between people, local topography and farming practices, which produced radial field systems around Çatalhöyük in the distant past, resulted in features that survived in the field morphology until at least the early 20 th century. The survival and perhaps repeated establishment or respecting of such radial systems are taphonomic processes which amplify the signal of a particular past action in a way which makes it durable and persistent, and testifies to its significance over the longue durée. Near the Çarşamba river at Çatalhöyük, ancient ground surfaces lie beneath multiple layers of alluvial soil built up sometimes to a depth of many metres. Alluvial landscapes of this kind and their associated field systems offer considerable potential for combining retrogressive map analysis with palaeoecological approaches in a manner that enables investigation of their taphonomy. Towards the other end of the scale of archaeological analysis, survey of the type conducted in this study is itself a taphonomic process. Field-walking and the collection of ceramics obviously alter the ceramic signal on the ground, but they also alter what we understand about the landscape. Our analyses of the map and remote-sensing data will also serve to contribute to people's understanding of Çatalhöyük. If we are considering landscapes as collections of actions and experiences, archaeological research is intrinsically taphonomic in the way that it alters our perception and contributes to the complex narratives of place.

\section{Acknowledgements}

We would like to thank the Turkish Ministry of Culture and Tourism, the British Institute at Ankara and the team at Çatalhöyük, particularly Ian Hodder, Ingmar Franz, Jason Quinlan, Shahina Farid, Scott Haddow and our government representative for 2013, Fahri Ayçin. We would like to acknowledge and thank both the Society for the Promotion of Roman Studies and the School of History, Classics and Archaeology at Newcastle University for their financial support of our fieldwork. The authors have benefitted from very helpful discussions with and assistance from members of the McCord Centre for Landscapes and the School of History, Classics and Archaeology at Newcastle University, particularly Sam Turner, Alex Turner, Francesco Carrer, Caron Newman and Katie Green, and from Jim Crow (Edinburgh), as well as members of the community at the Joukowsky Institute for Archaeology, Brown University, in particular John Cherry. The comments of our anonymous reviewers, Gina Coulthard and the editors of Anatolian Studies were invaluable and we are most grateful to the 2013 fieldsurvey team: Eniko Hudak, for her work on the ceramics, and Tom Sutcliffe, surveyor.

\section{Bibliography}

Baird, D. 1996: 'The Konya plain survey: aims and methods' in I. Hodder (ed.), On the Surface: Çatalhöyük $1993-95$. Cambridge/London, McDonald Institute for Archaeological Research/British Institute at Ankara: 41-46

- 2004: 'Settlement expansion on the Konya plain, Anatolia: 5th-7th centuries AD' in W. Bowden, L. Lavan, C. Machado (eds), Recent Research on the Late Antique Countryside. Leiden, Brill: 219-47

Bayliss, A., Brock, F., Farid, S., Hodder, I., Southon, J., Taylor, R.E. 2015: 'Getting to the bottom of it all: a Bayesian approach to dating the start of Çatalhöyük' Journal of World Prehistory 28: 1-26. https://doi.org/10.1007/s10963015-9083-7

Baysal, E., Elton, H. 2014: 'A tomb with a view: the rock-cut cemetery at Alahan in Isauria' Adalya 17: 181-208

Bevan, A., Conolly, J. 2004: 'GIS, archaeological survey, and landscape archaeology on the island of Kythera, Greece' Journal of Field Archaeology 29: 123-38. https://doi.org/10.1179/jfa.2004.29.1-2.123

Biehl, P., Anvari, J., Rosenstock, E. (eds) in preparation: The End of Catalhoyuk: The West Mound Excavations. Los Angeles: Cotsen Institute of Archaeology

Bintliff, J., Sbonias, K. 2000: 'Demographic trends: the contribution of regional survey data' in R. Francovich, H. Patterson (eds), Extracting Meaning from Ploughsoil Assemblages: The Archaeology of Mediterranean Landscapes. Oxford, Oxbow: 224-58

Bloch, M. 1995: 'People into places: Zafimaniry concepts of clarity' in E. Hirsch, M. O’Hanlon (eds), The Anthropology 
of Landscape: Perspectives on Place and Space. Oxford, Clarendon Press: 63-77

Bogaard, A., Isaakidou, V. 2010: 'From mega-sites to farmsteads: community size, ideology and the nature of early farming landscapes in western Asia and Europe' in B. Finlayson, G. Warren (eds), Landscapes in Transition. Oxford, Oxbow: 192-207

Bogaard, A., Krause, R., Strien. H.-C. 2011: 'Towards a social geography of cultivation and plant use in an early farming community: Vaihingen an der Enz, south-west Germany' Antiquity 85: 395-416. https://doi.org/10.1017/S0003598X00067831

Casana, J. 2013: 'Radial route systems and agro-pastoral strategies in the Fertile Crescent: new discoveries from western Syria and southwestern Iran' Journal of Anthropological Archaeology 32: 257-73.

https://doi.org/10.1016/j.jaa.2012.12.004

Charles, M., Doherty, C., Asouti, E., Bogaard, A., Henton, E., Spencer Larsen, C., Ruff, C.B., Ryan, P., Sadvari, J.W., Twiss, K.C. 2014: 'Landscape and taskscape at Çatalhöyük: an integrated perspective' in I. Hodder (ed.), Integrating Çatalhöyük: Themes from the 2000-2008 Seasons. Los Angeles/London, Cotsen Institute of Archaeology/British Institute at Ankara: 71-90

Chouquer, G. 2015: Les parcellaires médiévaux en Émilie et en Romagne Centuriations et trames coaxiales Morphologie et droit agraires. Paris, Observatoire des formes du foncier dans le monde France Internationale pour l'Expertise Foncière (FIEF)

Cottica, D., Hager, L.D., Boz, B. 2012: 'Post-Neolithic use of Building 3 (Space 86), Space 88 and Space 89' in R. Tringham, M. Stevanović (eds), Last House on the Hill: Bach Area Reports from Çatalhöyük, Turkey. Los Angeles, Cotsen Institute of Archaeology: 331-47

Council of Europe 2000: European Landscape Convention. Strasbourg, Cultural Heritage, Landscape and Spatial Planning Division, Directorate of Culture and Cultural and Natural Heritage. https://rm.coe.int/16802f80c6

Crow, J., Turner, S. 2009: 'Silivri and the Thracian hinterland of Istanbul: an historic landscape' Anatolian Studies 59: 167-81. https://doi.org/10.1017/S0066154600000958

Crow, J., Turner, S., Athanasios, K. 2011: 'Characterizing the historic landscapes of Naxos' Journal of Mediterranean Archaeology 24.1: 111-37. https://doi.org/10.1558/jmea.v24i1.111

Czerniak, L., Marciniak, A., Pyzel, J. 2002: 'The excavations of the TP (Team Poznań) Area in the 2002 season' in Çatalhöyük 2002 Archive Report. http://www.catalhoyuk.com:8080/archive_reports/2002/ar02_07.html

Davies, J. 1999: Death, Burial and Rebirth in the Religions of Antiquity. London/New York, Routledge. https://doi.org/10.4324/9780203288641

Equini Schneider, E. (ed.) 1999: Elaiussa Sebaste 1: Campagne di Scavo 1995-1997. Rome, Bretschneider

Fairbairn, A. 2005: 'A history of agricultural production at Neolithic Çatalhöyük East, Turkey’ World Archaeology 37.2: 197-210. https://doi.org/10.1080/00438240500094762

Filipowicz, P., Harabasz, K., Hordecki, J. 2014: 'Excavations in the TPC Area' in Çatalhöyük 2014 Archive Report: 72 79. http://www.catalhoyuk.com/archive_reports/2014

Francovich, R., Patterson, H. (eds) 2000: Extracting Meaning from Ploughsoil Assemblages: The Archaeology of Mediterranean Landscapes. Oxford, Oxbow

Franz, I., Ostaptchouk, S. 2012: 'Illuminating the pottery production process at Çatalhöyük West Mound (Turkey) around 8000 cal. BP' in B. Ramminger, O. Stilborg (eds), Naturwissenschaftliche Analysen vor- und frühgeschichtlicher Keramik 2: Methoden, Anwendungsbereiche, Auswertungsmöglichkeiten. Bonn, Habelt

Given, M. 2013: 'Commotion, collaboration, conviviality: Mediterranean survey and the interpretation of landscape' Journal of Mediterranean Archaeology 26.1: 3-26. https://doi.org/10.1558/jmea.v26i1.3

Given, M., Knapp, A.B., Noller, J.S., Sollars, L., Kassianidou, V. (eds) 2013: Landscape and Interaction: The Troodos Archaeological and Environmental Survey Project, Cyprus (2 vols). London, Council for British Research in the Levant

Green, K.L. 2013: Rural Byzantine Landscapes and Societies: New Approaches to Characterisation and Analysis. PhD thesis, Newcastle University

Greene, K. 2005: 'Roman pottery: models, proxies and economic interpretation' Journal of Roman Archaeology 18: 34-56. https://doi.org/10.1017/S1047759400007200

Hamilakis, Y. 2013: The Archaeology of the Senses. Cambridge, Cambridge University Press. https://doi.org/10.1017/CBO9781139024655

Herzfeld, E., Guyer, S. 1930: Meriemlik und Korykos (Monumenta Asiae Minoris Antiqua 2). Manchester, Manchester University Press 
Hodder, I. 1996: 'Re-opening Çatalhöyük' in I. Hodder (ed.), On the Surface: Çatalhöyük 1993-95. Cambridge/London, McDonald Institute for Archaeological Research/British Institute at Ankara: 1-18

- 2006: Çatalhöyük: The Leopard's Tale. Revealing the Mysteries of Turkey's Ancient 'Town'. London, Thames \& Hudson

— 2013: 'Introduction: dwelling at Çatalhöyük' in I. Hodder (ed.), Humans and Landscapes of Çatalhöyük: Reports from the 2000-2008 Seasons. Los Angeles/London, Cotsen Institute of Archaeology/British Institute at Ankara: $1-29$

- 2014: 'Mosaics and networks: the social geography of Çatalhöyük' in I. Hodder (ed.), Integrating Çatalhöyük: Themes from the 2000-2008 Seasons. Los Angeles/London, Cotsen Institute of Archaeology/British Institute at Ankara: 149-67

Hoeffelman, R. 1913: 'De irrigatiewerken in de vlakte van Konia' Klein Azië'Ingenieur 28: 513-71

Holz, M., Simões, M.G., 2005: 'Taphonomy: overview of main concepts and applications to sequence stratigraphic analysis' in E.A.M. Koutsoukos (ed.), Applied Stratigraphy. Dordrecht, Springer: 249-78. https://doi.org/10.1007/14020-2763-X_12

Hordecki, J. 2015: Post-chalkolityczne osadnictwo w strefie TP na stanowisku Çatalhöyük, Turcja. MA thesis, Poznan University

Howard, P., Thompson, I., Waterton, E. (eds) 2013: The Routledge Companion to Landscape Studies. London, Routledge Ingold, T. 1993: 'The temporality of the landscape' World Archaeology 25.2: 152-74. https://doi.org/10.1080/00438243.1993.9980235

Jackson, M. 2017: 'Building on the past: Gertrude Bell and the transformation of space in the Karadağ' in Y. Heffron, A. Stone, M. Worthington (eds), At the Dawn of History: Ancient Near Eastern Studies in Honour of J.N. Postgate 1. Winona Lake, Eisenbrauns: 239-54

Jackson, M., Moore, S., Hudak, E., Sutcliffe, T. 2013: 'Survey and fieldwalking in the immediate environs of Çatalhöyük 2013' in Çatalhöyük 2013 Archive Report: 265-71. http://www.catalhoyuk.com/archive_reports/2013

Jenks, G.F. 1967: 'The data model concept in statistical mapping' International Yearbook of Cartography 7: 186-90

Kinnaird, T.C., Bolòs, J., Turner, A., Turner, S. 2017: 'Optically-stimulated luminescence profiling and dating of historic agricultural terraces in Catalonia (Spain)’ Journal of Archaeological Science 78: 66-77. https://doi.org/10.1016/j.jas.2016.11.003

Kwiatkowska, M. 2009: 'Byzantine and Muslim cemeteries at Çatalhöyük: an outline' in T. Vorderstrasse, J. Roodenberg (eds), Archaeology of the Countryside in Medieval Anatolia. Leiden, Nederlands Instituut voor het Nabije Oosten: $129-38$

Last, J. 1996: 'Surface pottery at Çatalhöyük' in I. Hodder (ed.), On the Surface: Çatalhöyük 1993-95. Cambridge/London, McDonald Institute for Archaeological Research/British Institute at Ankara: 115-71

Liddell, H.G., Scott R. 1968: A Greek-English Lexicon. Oxford, Oxford University Press

Marciniak, A., Moore, S. in preparation: 'The other Çatalhöyük: proto-historic settlement and historic cemetery'

Matthews, R. 1996: 'Surface scraping and planning' in I. Hodder (ed.), On the Surface: Çatalhöyük 1993-95. Cambridge/London, McDonald Institute for Archaeological Research/British Institute at Ankara: 79-99

Matthews, R., Glatz, C. 2009: At Empires'Edge. Project Paphlagonia: Regional Survey in North-Central Turkey. London, British Institute at Ankara

Mele, M., Cremaschi, M., Giudici, M., Lozej, A., Pizzi, C., Bassi, A. 2013: 'The Terramare and the surrounding hydraulic structures: a geophysical survey of the Santa Rosa site at Poviglio (Bronze Age, northern Italy)' Journal of Archaeological Science 40: 4648-62. https://doi.org/10.1016/j.jas.2013.06.033

Mellaart, J. 1962: 'Excavations at Çatal Hüyük: first preliminary report, 1961' Anatolian Studies 12: 41-65. https://doi.org/10.2307/3642517

— 1963: 'Excavations at Çatal Hüyük: second preliminary report, 1962' Anatolian Studies 13: 43-103. https://doi.org/10.2307/3642490

— 1964: 'Excavations at Çatal Hüyük: third preliminary report, 1963' Anatolian Studies 14: 39-119. https://doi.org/10.2307/3642466

— 1966: 'Excavations at Çatal Hüyük: fourth preliminary report, 1965' Anatolian Studies 16: 165-91. https://doi.org/10.2307/3642483

— 1967: Çatal Hüyük: A Neolithic Town in Anatolia. London, Thames \& Hudson

Moore, S. 2012: 'Community fieldwalking' in Çatalhöyük 2012 Archive Report: 260. http://www.catalhoyuk.com/archive_reports/2012 
- 2014a: 'Analysis of the post-Chalcolithic cemeteries' in Çatalhöyük 2014 Archive Report: 203. http://www.catalhoyuk.com/archive_reports/2014

— 2014b: 'Burials and identities at historic period Çatalhöyük' Heritage Turkey 4: 29. https://doi.org/10.18866/biaa2015.096

Moore, S., Gamble, M. 2015: 'Bodies of evidence: the historic cemeteries of Çatalhöyük' Heritage Turkey 5: 13-14. https://doi.org/10.18866/biaa2015.111

— 2016: 'A Roman woman from Çatalhöyük' Heritage Turkey 6: 32-34. https://doi.org/10.18866/biaa2016.034

Moore, S., Jackson, M. 2014: 'Late burials from the 4040 Area of the East Mound' in I. Hodder (ed.), Çatalhöyük Excavations: The 2000-2008 Seasons. Los Angeles/London, Cotsen Institute of Archaeology/British Institute at Ankara: $603-20$

Olsen, B., Shanks, M., Webmore, T., Witmore, C. 2012: Archaeology: The Discipline of Things. Berkeley/Los Angeles/ London, University of California Press. https://doi.org/10.1525/california/9780520274167.001.0001

Orton, D., Anvari, J., Gibson, C., Last, J., Bogaard, A., Rosenstock, E., Biehl, P. in preparation: 'A tale of two tells: dating the Catalhoyuk West Mound'

Poblome, J. 1999: Sagalassos Red Slip Ware: Typology and Chronology. Turnhout, Brepols

Poidebard, A. 1934: La trace de Rome dans le desert de Syrie. Paris, Geuthner

Pollard, T., Shell, C.A., Twigg, D.R. 1996: 'Topographic survey of the Çatalhöyük mounds' in I. Hodder (ed.), On the Surface: Çatalhöyük 1993-95. Cambridge/London, McDonald Institute for Archaeological Research/British Institute at Ankara: 59-72

Porteous, J.D. 1990: Landscapes of the Mind: Worlds of Sense and Metaphor. Toronto, University of Toronto Press

Roberts, N., Black, S., Boyer, P., Eastwood, W., Griffiths, H., Lamb, H., Leng, M., Parish, R., Reed, J., Twigg, D. 1999: 'Chronology and stratigraphy of Late Quaternary sediments in the Konya basin, Turkey: results from the KOPAL Project' Quaternary Science Reviews 18.4-5: 611-30

Roberts, N., Boyer, P., Merrick, J. 2007: 'The KOPAL research programme at Çatalhöyük (1996-2001)' in I. Hodder (ed.), Excavating Çatalhöyük: South, North and KOPAL Area Reports from the 1995-1999 Seasons. Cambridge/London, McDonald Institute for Archaeological Research/British Institute at Ankara: 553-80

Roberts, N., Boyer, P., Parish, R. 1996: 'Preliminary results of geoarchaeological investigations at Çatalhöyük' in I. Hodder (ed.), On the Surface: Çatalhöyük 1993-95. Cambridge/London, McDonald Institute for Archaeological Research/British Institute at Ankara: 19-40

Rutter, J.B. 1983: 'Some thoughts on the analysis of ceramic data generated by site surveys' in D. Keller, D Rupp (eds), Archaeological Survey in the Mediterranean Area. Oxford, British Archaeological Reports

Sanders, G. 2000: 'New relative and absolute chronologies for 9th to 13th century glazed wares at Corinth: methodology and social conclusions' in K. Belke, F. Hild, J. Koder, P. Soustal (eds), Byzanz als Raum: Zu Methoden und Inhalten der historischen Geographie des östlischen Mittelmeerraumes im Mittelalter. Vienna, Österreichische Akademie der Wissenschaften: 153-74

Schiffer, M.B. 1972: ‘Archaeological context and systemic context' American Antiquity 37.2: 156-65. https://doi.org/10.2307/278203

Shankland, D. 1996: 'Çatalhöyük: the anthropology of an archaeological presence' in I. Hodder (ed.), On the Surface: Çatalhöyük 1993-95. Cambridge/London, McDonald Institute for Archaeological Research/British Institute at Ankara: $349-58$

Shanks, M., Witmore, C. 2010: 'Echoes across the past: chorography and topography in antiquarian engagements with place' Performance Research 15.4: 97-106. https://doi.org/10.1080/13528165.2010.539888

Turner, S., Crow, J. 2010: 'Unlocking historic landscapes in the eastern Mediterranean: two pilot studies using historic landscape characterisation' Antiquity 84: 216-29. https://doi.org/10.1017/S0003598X00099889

Ur, J. 2003: 'CORONA satellite photography and ancient road networks: a northern Mesopotamian case study' Antiquity 77: 102-15. https://doi.org/10.1017/S0003598X00061391

van Liere, W.J., Lauffray, J. 1954-1955: 'Nouvelle prospection archéologique dans la Haute Jazireh Syrienne’ Les annales archéologiques arabes syriennes 4/5: 129-48

Wilkinson, T.J. 1993: 'Linear hollows in the Jazira, upper Mesopotamia' Antiquity 67: 548-62. https://doi.org/10.1017/S0003598X00045750

- 2003: Archaeological Landscapes of the Near East. Tucson, University of Arizona Press

Witmore, C. 2007: 'Symmetrical archaeology: excerpts from a manifesto' World Archaeology 39.4: 546-62

Yeomans, L. 2014: 'Building 31' in I. Hodder (ed.), Çatalhöyük Excavations: The 2000-2008 Seasons. Los Angeles/London, Cotsen Institute of Archaeology/British Institute at Ankara: 597-602 